\title{
VOLATILITY OF GDP, MACRO APPLICATIONS AND POLICY IMPLICATIONS OF REAL OPTIONS FOR STRUCTURE OF CAPITAL MARKETS
}

\author{
José Pablo Dapena \\ UNIVERSIDAD DEL CEMA \\ 541163143000 ext 780 \\ jd@cema.edu.ar
}

The traditional marshallian rule of investing (abandoning) when the value of an underlying asset is above (below) the cost of an alternative investment is modified in the presence of uncertainty and irreversibility giving rise to an option component into decisions. This component is affected by the degree of volatility of underlying assets, which in turn can derive their volatility from the economy as a whole, affecting the investment process and therefore the accumulation of capital and future growth. In the same tense, the evidence of volatility in the returns of the underlying assets of the economy affects the market value of debt contracts, conveying recommendations regarding the financial architecture of the economy and the type of financial instruments better suited. The paper explores the application of contingent claims analysis both to the potential effect of macro volatility on aggregate investment, and to the effect on the presence of high levels of indebtedness of the economy, with a special application to the Argentinean economy where we obtain that economies with high level of volatility would require a significant level of internal saving and capital markets driven mainly by equity instruments of financing, which helps to better accommodate uncertainty by means of the price of assets.

JEL: G00, F36, O16.

Key words: volatility, contingent claims, real options, aggregate investment, saving, capital markets.

The present paper has been selected for presentation at the $10^{\text {th }}$ Annual Conference on Real Options held in June 2005 at Columbia Business School. Statements and opinions conveyed in this paper are attributable to the autor, while Universidad del CEMA disclaims any responsibility for them. 
"The lack of a spare tire is not a concern until we get a flat one"

Anonymous

\section{Introduction}

The fundaments of investment are treated in Fisher (1930) and Hirschleifer (1958), where agents decide based on the comparison between the present value of future consumption and the current cost. The traditional marshallian rule sets to invest if the present value $\mathrm{V}$ of the underlying asset is greater than its installment cost I. For the purpose of determination of $\mathrm{V}$, the generally accepted method is the discount of expected future cash flows generated by the investment through the use of a discount rate that appropriately reflects the risk class of the underlying cash flows. However, in the face of uncertainty and irreversibility, considerations exposed in Dixit and Pyndick (1994) have to be taken into account, where the investment decision can be associated to a call option, affecting rules of investment taken for granted ${ }^{1}$. In this tense, Myers (1977) is the first to notice that every investment opportunity can be decomposed into two components, capital already in place and growth options, resembling the later financial call options on future cash flows. Mc Donald and Siegel (1984, 1985 y 1986) show similarities between financial options and real capital investment (growth and waiting decisions as call options, and abandonment decisions as a put options. This approach has been extensively covered and continued by Trigeorgis (1988 and 1997 for instance).

The investment process is then crucial for economic growth, and economic growth requires sustained investment, which takes place financed through savings and capital markets. The interrelation between financial intermediation and economic growth is object of study in the literature, with relevant research by Levine (1997), Miller (1998), and Rajan and Zingales (1998), which provide evidence of a positive relationship between the degree of development of the financial system and economic growth. In this sense one of the first empirical papers is by Levine and Zerbos (1998) showing two interesting points, first the statistical significance of financial intermediation in the explanation of economic development, and second statistical evidence showing that both the banking system and the capital markets are individually significant to explain

\footnotetext{
${ }^{1}$ The contingent claim methodology of valuation was first treated by Black and Sholes (1973) and Merton (1973) aimed to value financial options; Cox, Ross and Rubinstein (1979) contributed to the literature introducing the methodology of risk neutral valuation.
} 
economic development, which suggests that they perform different functions within the economy.

In the study of economic growth it is often emphasized the analysis of the average rate of growth of both the economy as a whole and the per capita GDP; however the standard deviation of the rate of growth could be relevant as well to explain the aggregate process of investing, real capital accumulation and economic growth. In line with this and aimed to emerging markets, its is possible to identify literature about structural volatility of an economy, generally related to the institutional environment of the economy and the financial system as a whole. Caballero and Krishnamurty (1998) associate high volatility periods to the lack of sufficient collateral in the economy (not enough external collateral first, affecting then the availability of internal collateral), this suggestion is extended in Caballero and Krishnamurty (2001), while Caballero (2000a and 2000b) study evidence of volatility in Latin America in three case studies of countries, associating it to weak international links (real and financial) and to underdeveloped domestic financial system, which makes the economy sensitive to changes in the direction of international capital movements. These considerations regarding vulnerability to changes in capital flows is subject of study in Calvo (1998) through a "balance sheet" approach linking the flow of international capital, the level of net external assets and the current account of an economy, where a sudden reversal in the direction of capital flows may give rise to a crisis in economies highly dependant of them. More recently Ridditz (2003) relates volatility in per capita GDP to liquidity of the financial system, finding evidence that more liquidity in the system tends to reduce volatility (intuitively, the existence of credit smoothes the changes in aggregate demand).

The variability of the business cycle and its relation to the aggregate structure of finance is also study. Bernanke and Gertler $(1989,1990)$ study the relation between financial stability and the performance of an economy in a framework based in the solution to agency costs (inspired form Jensen and Meckling 1976), where they develop about the effect of corporate indebtness, the generation of internal savings and the election of the financial instruments. In the same tense we found the work of Greenwald and Stiglitz (1993) showing a model of interaction between the business cycle and the type of financial instruments used in the economy from an asymmetric information perspective 
where the use of debt instruments is revealed as efficient ${ }^{2}$. Kiyotaki and Moore (1997) build up a dynamic model stressing the importance in the economy of the kind of assets used as collateral of debt and their influence in the business cycle. More recently Gray, Merton et. al. (2003) show a contingent claims approach the analysis of cross credit relationships and aggregate management of risk in an economy.

The references mentioned above consider the structure of finance and the election of financial instruments in the aggregate, but the literature regarding the efficient choosing of financial instruments starts with the seminal paper of Modigliani and Miller (1958) giving rise to the formal study of corporate finance. In the paper, the authors propose their famous irrelevance theorem, where the election of financial instruments becomes relevant when original assumptions are relaxed ${ }^{3}$ : considerations regarding tax issues both at the firm and at an individual level (Miller 1977, DeAngelo and Masulis 1980), transaction costs stemming from bankruptcy processes (Stiglitz 1969), clientele effects (Allen and Gale 1988), agency problems (Jensen and Meckling 1976 already mentioned) and asymmetric information in financial markets (Leland and Pyle 1977, Stiglitz and Weiss 1981) among an extended literature ${ }^{4}$ (see Myers 1977 and 1984, etc.) aim to explain why corporations tend to choose a financial instrument to finance their operations.

\section{The proposal to be developed}

The structure of references to the literature mentioned above shows literature about the investments process, research on structural volatility of the GDP, financial structure, financial instruments and investment decisions in the context of uncertainty and irreversibility. Based on this lines of research, it is the object of this paper to propose a contingent claim approach to help understand the impact of aggregate volatility in the process of investment, accumulation of capital and economic growth, and in the development of capital markets and financial instruments.

\footnotetext{
${ }^{2}$ Rajan and Zingales (1998) elaborates a clever methodology to measure the degree of development of the financial system, based on the relative use by firms of internal capital markets and external (to the firm) capital markets.

${ }^{3}$ See any corporate finance textbook.

${ }^{4}$ To the purpose of a detailed explanation of the different theories aiming to explain the use of financial instruments, see Harris and Raviv (1991a).
} 
In the next section we show empirical evidence of historical volatility of real GDP for an extended set of countries; we develop after a stylized model relating volatility of GDP and volatility of returns in the value of assets, formalizing the interaction through a regression analysis. We finally study considerations regarding the financial structure of an economy in the face of structural volatility through contingent claims analysis, where we obtain that economies with high level of volatilities should develop strong capital markets driven mainly by equity instruments of financing and internal savings, which helps to better accommodate uncertainty by means of price.

\section{Volatility of the rate of growth of real GDP}

We start analyzing the dynamic behavior of real GDP for different economies during an extended period of time. Studies about growth tend generally to focus only on the average rate of growth, both at the aggregate or in a per capita basis; the purpose of this section is to generate and approach that helps introduce volatility of that rate as well as a tool of analysis. We gather statistics of real GDP (GDP Volume base $1995=100$ ) from, IMF data series from 1970 to 2004 obtaining the standard deviation of the rate of growth; a high standard deviation may be representative of a highly uncertain economy. Showing the results, we group countries in four regions representing economic development and geographical distribution: I - Industrialized countries (G-7), II - Rest of Europe, III- Latin America and IV -Asia Pacific.

The following table shows the results for three overlapped periods of time: from 1970 to 2004, from 1985 to 2004, and from 1990 to 2004:

Table 1 International comparison of volatility of real GDP rates of growth

\begin{tabular}{ccc} 
Estimated & Estimated & Estimated \\
Volatility & Volatility & Volatility \\
$1970-2004$ & $1985-2004$ & $1990-2004$ \\
\hline
\end{tabular}

\begin{tabular}{ccc} 
Estimated & Estimated & Estimated \\
Volatility & Volatility & Volatility \\
$1970-2004$ & $1985-2004$ & $1990-2004$ \\
\hline
\end{tabular}

I - INDUSTRIALIZED

COUNTRIES G-7

Germany $\quad 2,6 \%$

Japan

$2,4 \%$

Canada
$2,9 \%$

$2,1 \%$

$1,9 \%$
III - LATIN

AMERICA

$\begin{array}{llll}\text { Chile } & 5,9 \% & 3,1 \% & 3,2 \%\end{array}$

Argentina $\quad 5,7 \% \quad 6,5 \% \quad 6,8 \%$

Venezuela $\quad 5,6 \% \quad 6,5 \% \quad 7,8 \%$ 


\begin{tabular}{|c|c|c|c|c|c|c|c|}
\hline USA & $2,1 \%$ & $1,3 \%$ & $1,2 \%$ & Ecuador & $5,4 \%$ & $3,7 \%$ & $3,4 \%$ \\
\hline UK & $2,0 \%$ & $1,6 \%$ & $0,6 \%$ & Peru & $5,3 \%$ & $5,9 \%$ & $2,9 \%$ \\
\hline Italy & $1,9 \%$ & $1,2 \%$ & $0,9 \%$ & Uruguay & $5,0 \%$ & $5,2 \%$ & $6,3 \%$ \\
\hline \multirow[t]{2}{*}{ France } & $1,5 \%$ & $1,3 \%$ & $1,2 \%$ & Brazil & $4,2 \%$ & $2,4 \%$ & $1,8 \%$ \\
\hline & & & & Paraguay & $3,9 \%$ & $2,2 \%$ & $2,0 \%$ \\
\hline II- EUROPE & & & & Mexico & $3,6 \%$ & $3,2 \%$ & $3,9 \%$ \\
\hline Portugal & $3,1 \%$ & $2,3 \%$ & $1,8 \%$ & Bolivia & $2,8 \%$ & $2,2 \%$ & $1,6 \%$ \\
\hline Ireland & $2,8 \%$ & $2,8 \%$ & $2,6 \%$ & Colombia & $2,3 \%$ & $2,3 \%$ & $2,6 \%$ \\
\hline Switzerland & $2,2 \%$ & $1,6 \%$ & $1,2 \%$ & & & & \\
\hline Spain & $2,1 \%$ & $1,6 \%$ & $0,9 \%$ & $\begin{array}{l}\text { IV - ASIA } \\
\text { Hong }\end{array}$ & CIFIC & & \\
\hline Denmark & $1,9 \%$ & $1,5 \%$ & $0,9 \%$ & Kong & $4,7 \%$ & $4,1 \%$ & $4,1 \%$ \\
\hline Austria & $1,9 \%$ & $1,1 \%$ & $1,0 \%$ & Thailand & $4,2 \%$ & $5,1 \%$ & $5,5 \%$ \\
\hline Sweden & $1,8 \%$ & $1,9 \%$ & $1,3 \%$ & Malaysia & $4,0 \%$ & $4,7 \%$ & $5,3 \%$ \\
\hline Norway & $1,8 \%$ & $1,6 \%$ & $1,5 \%$ & Indonesia & $4,0 \%$ & $4,6 \%$ & $6,1 \%$ \\
\hline \multirow[t]{6}{*}{ Netherlands } & $1,7 \%$ & $1,4 \%$ & $1,7 \%$ & Korea & $3,8 \%$ & $4,0 \%$ & $4,7 \%$ \\
\hline & & & & China & $3,1 \%$ & $3,1 \%$ & $1,1 \%$ \\
\hline & & & & India & $3,0 \%$ & $1,8 \%$ & $1,3 \%$ \\
\hline & & & & New & & & \\
\hline & & & & Zealand & $2,7 \%$ & $2,5 \%$ & $1,5 \%$ \\
\hline & & & & Australia & $1,8 \%$ & $1,6 \%$ & $1,1 \%$ \\
\hline
\end{tabular}

We observe from the table that Latin-American and Asian economies have had higher levels of volatility than their industrialized and european counterparts. We can also see changes in the level of volatility for some countries (like Chile, having a high level of volatility in the first column, and falling in the second and third column ${ }^{5}$, the brazilian economy follows a similar pattern). The cases of Thailand, Malaysia and Indonesia are worth seeing as well, very stable in the long run, but volatile in the nineties, which may have been caused by the crisis. A very special case is that of Argentina, which shows not only one of the highest levels of volatility, but also persistent in time.

Continuing with the comparison, we broaden the analysis to introduce the average rate of growth. The two parameters are plotted in the following graph, showing on the horizontal axis the average rate of growth and volatility on the vertical axis. We also divide the space in four areas:

- low average rate of growth - low volatility (A),

- $\quad$ high average rate of growth - high volatility (C),

- high average rate of growth - low volatility (B),

- low average rate of growth - high volatility (D).

\footnotetext{
${ }^{5}$ Likely consequences of structural reforms undertaken in the ' 80 's .
} 
If we consider the rate of growth as a positive attribute, and the volatility as a negative one (uncertainty in the economy), we can propose that attractive investment conditions require that high levels of uncertainty should be compensated with high rates of growth $^{6}$, therefore the areas where we expect to find observations are A and C. In the same tense, the most attractive region is B, and the worst D. The following graph shows observations from 1970 to 2004 :

\section{Graph 1 Relationship between aggregate rate of growth and volatility $1970-2004$}

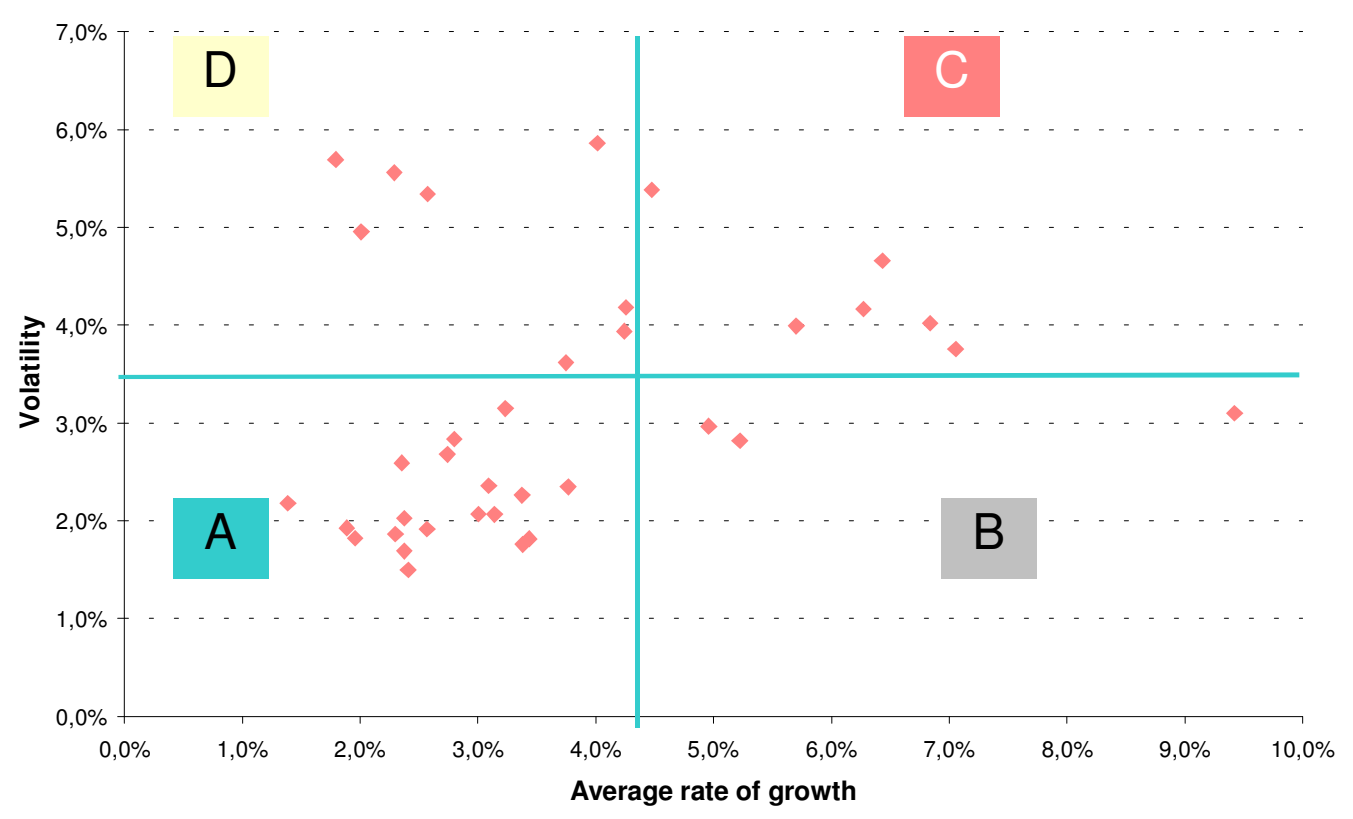

\begin{tabular}{lllll}
\hline A- Low Volatility and Low & 1970-2004 & & \\
Growth & $\begin{array}{c}\text { B- Low Volatility and } \\
\text { High Growth }\end{array}$ & $\begin{array}{l}\text { C- High Volatility } \\
\text { and High Growth }\end{array}$ & $\begin{array}{c}\text { D- High Volatility } \\
\text { and Low Growth }\end{array}$ \\
\hline Germany & Italy & Irlanda & Indonesia & Perú \\
Australia & Japan & China & Thailand & Argentina \\
Austria & Norway & India & Hong Kong & Venezuela \\
Bolivia & New Zealand & & Malasia & Brazil \\
Canada & Portugal & & Korea & Paraguay \\
Colombia & United Kingdom & Ecuador & Mexico \\
Denmark & Sweden & & & Uruguay \\
Spain & Switzerland & & Chile \\
United States & & & \\
$\begin{array}{l}\text { France } \\
\text { Netherlands }\end{array}$ & & &
\end{tabular}

\footnotetext{
${ }^{6}$ A very simple risk and return approach on the aggregate.
} 
Industrialized economies tend to fall in region A and Asian economies in region $\mathrm{C}$. The more attractive region shows two countries that have grown at high and stable rates: Ireland and China; finally region $\mathrm{C}$ groups mainly Latin-American countries.

Considering since 1985:

Graph 2 Relationship between aggregate rate of growth and volatility 1985 -2004

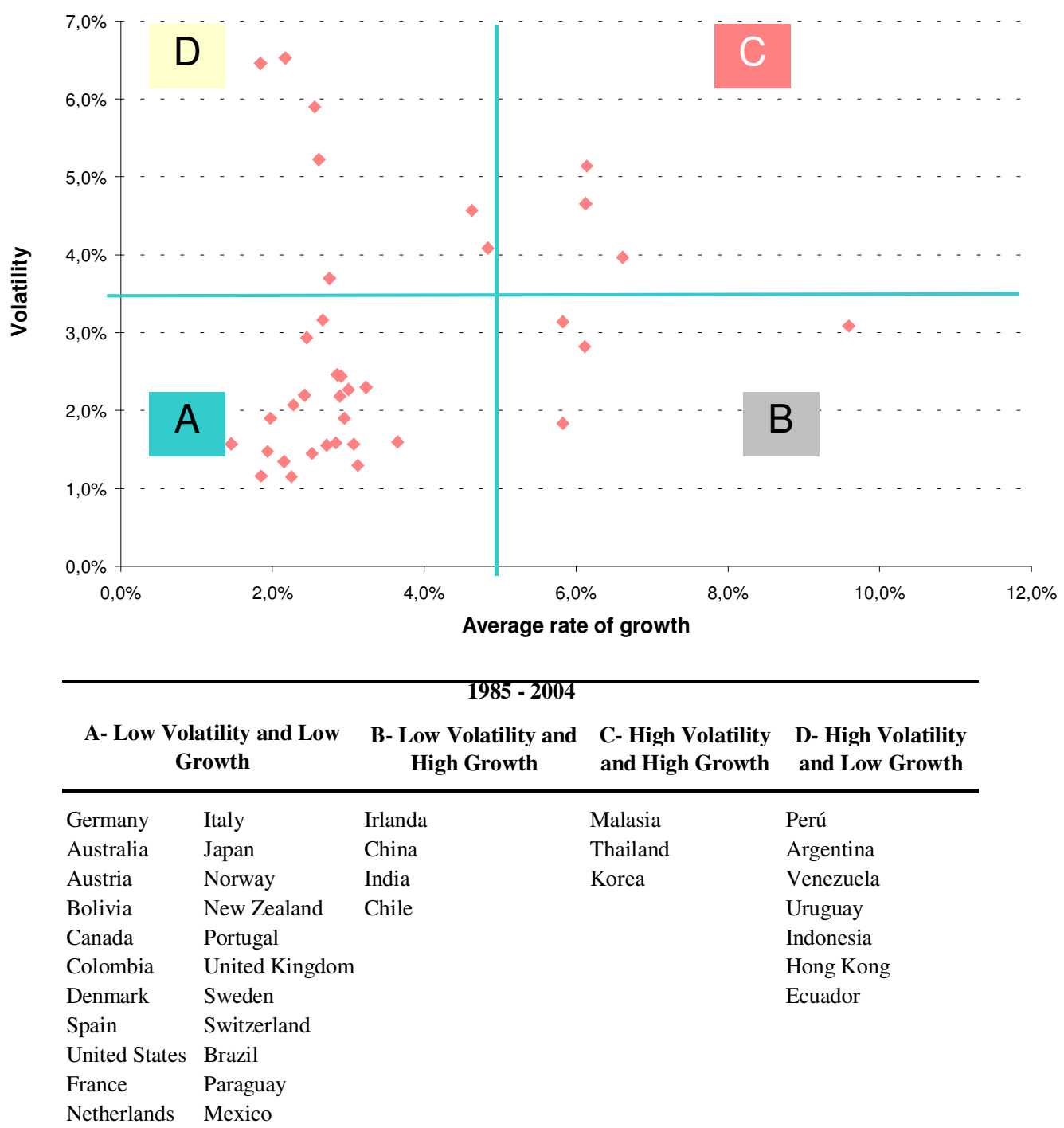

We observe results tend to be similar; however, there are some interesting cases. Now the attractive region $\mathrm{B}$ includes Chile and India and Brazil moves to region A. The argentinean economy remains as one with high volatility and low growth. 
We finally show the period of time from 1990 to 2004 (period of crisis for Asian economies) showing the following results:

\section{Graph 3 Relationship between aggregate rate of growth and volatility 1990 -2004}

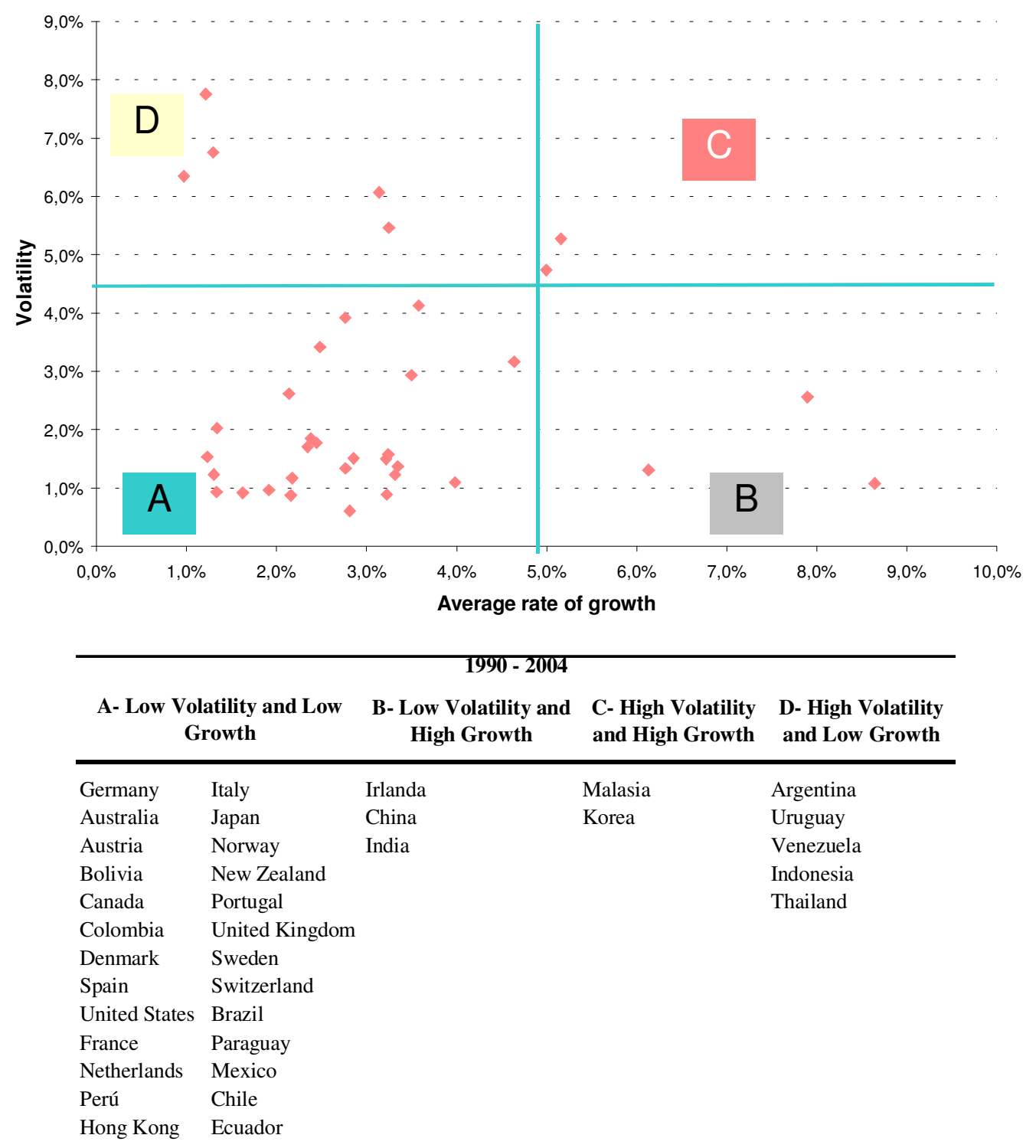

We can see the following cases: the Chilean economy keeps its high level of growth, now with high level of volatility (due likely to contagion from the Asian crisis); Asian economies lose growth but remain volatile (recall the crisis); the brazilian economy remains in the low growth low volatility region; the interesting case is the german economy, showing a high level of volatility due likely to the reunification process; the Argentinean economy keeps its position as one with the highest levels of volatility (recall that the nineties where supposed to be a golden period for the country) barely increasing the average rate of growth. 
In short:

- industrialized countries show low level of growth but also low level of volatility

- the cases of China, Chile, Ireland and India are of much interest.

- many Latin-American countries tend to fall in the region of low growth and high volatility, with the special case of Argentina.

- countries belonging to Asia Pacific tend to show high volatility but high growth as well.

Without getting into the likely causes of the results shown ${ }^{7}$, we shall now proceed to show the potential effects that volatility may cause in the investment decision process and the architecture of the financial system.

\section{Potential effects of the volatility of the rate of growth on aggregate investment}

\subsection{Effects of volatility in the investment process}

The economy produces an aggregate output $\mathrm{Q}_{\mathrm{t}}$ in a certain period of time using a set of different resources which includes the stock of capital K,:

$\mathrm{Q}_{\mathrm{t}}=\mathrm{f}\left(\mathrm{K}_{\mathrm{t}-1}, \Phi\right)$

where $\Phi$ represents the set of resources (like labor and technology) also used in the production process. According the generally accepted models in the literature, the first derivative and the second of $\mathrm{Q}$ with respect to $\mathrm{K}$ (keeping $\Phi$ constant) are positive and negative respectively, showing decreasing returns. The stock of capital at each moment of time is given, and is increased through the investment process $\mathrm{I}_{\mathrm{t}}$. If we take the set $\Phi$ as given, there would be an optimal level of capital $\mathrm{K}^{*}$ associated to a particular level of output, where the investment process adjusts in time the current level $\mathrm{K}$ to that level: 
$I_{t}=K_{t}-K_{t-1}-\pi K_{t-1}$

where $\pi$ represents the depreciation rate and (2) states that the stock of capital changes every period of time when gross investment $\mathrm{I}^{8}$ is above or below the depreciation $\pi \mathrm{K}^{9}$. Changes in output growth expectations may change the perceived desired stock of capital $\mathrm{K}^{*}$, and provided that the current stock of capital is given and cannot jump to adjust $^{10}$ given that changes occur slowly through the investing and depreciation process, its is relevant to introduce a "shadow" real price q of installed capital, which helps to instantaneously adjust the market value $\mathrm{V}$ of capital to changes in expectations and potential imbalances between the current stock of capital and the desired until the investment process clears the imbalance. Tobin (1969) introduced the variable q, defined as the ratio between the "market value of the capital goods or rights on them" with respect to its "installment cost"11:

$\mathrm{V}_{\mathrm{t}}=\mathrm{q}_{\mathrm{t}} * \mathrm{~K}_{\mathrm{t}-1}$

The underlying idea is that if the ratio q exceeds one, the economy can take advantage of it by increasing investment. Hence we should see agents investing when the ratio is greater than one, and disinvesting when the ratio is below one. The traditional rule of investment sets to invest when $\mathrm{V}>\mathrm{K}$ or similarly when $\Delta \mathrm{V}>\Delta \mathrm{K}=\mathrm{I}$ ( $\mathrm{q}>1$ according to (3)). However, we shall bear in mind the considerations of Dixit and Pyndick $(1994)^{12}$, where the in the presence of uncertainty and irreversibility the investment process can be seen as a call option written on asset $\mathrm{V}$ (the present value of future cash flows stemming from the asset) with exercise price I (the investment) with market value for the waiting option of $\mathrm{W}$ (opportunity of waiting under the presence of uncertainty and irreversibility). The option value $\mathrm{W}$ derives its value form the underlying asset $\mathrm{V}$ in

\footnotetext{
${ }^{7}$ For a development of causes of structural volatility, see Caballero (2000).

${ }^{8}$ Investment is defined as gross investment.

${ }^{9}$ In the remaining of the paper we shall omit this term, without affecting significantly the results.

${ }^{10}$ Obstfeld and Rogoff (1996) formally introduce adjustment costs in the capital accumulation process to show that the stock of capital cannot instantaneously jump, which gives rise to the variable q.

${ }^{11}$ We can also get a proxy of such a value $\mathrm{q}$ by observing the market value of firms with respect to its aggregate book value or installment cost.

12 The opportunity cost of the investment is not only the alternative use I, but also the embedded cost deriving from loosing the waiting option.
} 
the form $\mathrm{W}(\mathrm{V})$; to obtain its closed form solution, we assumed as usual a geometric Brownian motion for $\mathrm{V}$ of the form:

$\mathrm{dV}=\alpha \mathrm{Vdt}+\sigma \mathrm{Vdz}$

where $\sigma$ reflects the instantaneous volatility of $\mathrm{V}$. The value of the perpetual call option $\mathrm{W}$ is obtained in a standard way:

$$
\mathrm{W}(\mathrm{V})= \begin{cases}(\mathrm{I} /(\beta-1))^{1-\beta}(1 / \beta)^{\beta} \mathrm{V}^{\beta} & \text { para } \mathrm{V}<\mathrm{V}^{*} \\ \mathrm{~V}-\mathrm{I} & \text { para } \mathrm{V} \geq \mathrm{V}^{*}\end{cases}
$$

where

$\mathrm{V}^{*}=\mathrm{I} \beta /(\beta-1)>\mathrm{I}$

and

$\beta=\frac{-\left(\mathrm{r}-\delta-\sigma^{2} / 2\right)+\sqrt{\left(\mathrm{r}-\delta-\sigma^{2} / 2\right)^{2}+2 \mathrm{r} \sigma^{2}}}{\sigma^{2}}>1$

with

$\frac{\partial \beta}{\partial \sigma^{2}}<0$

where $\delta>\mathrm{r}$ to ensure convergence and exercise in finite time of the investment option.

Equation (7) shows the level of $\mathrm{V}$ at which it becomes optimal to invest and "kill" the waiting option. We observe that given $\beta>1, \beta /(\beta-1)>1$, the rule of investing when $\mathrm{V}$ $>\mathrm{I}$ is incomplete because $\mathrm{V}$ should reach the optimal value $\mathrm{V}^{*}$ for the decision to be optimal; uncertainty and irreversibility create a waiting option value and investing means to "kill" the option to wait, giving rise to an the opportunity cost $\mathrm{W}(\mathrm{V})$ which when added to the installment cost I may cause periods of time where V is above I (or q 
is greater than one) without triggering the investment process (given that $\mathrm{V}$ is not high enough to compensate the value lost by killing the option to wait). To trigger investment in the context of uncertainty $\mathrm{V}$ has to exceed the installment cost and also the option value of waiting, in the form $\mathrm{V} \geq \mathrm{I}+\mathrm{W}(\mathrm{V})^{13} \mathrm{o}$ alternatively $\mathrm{V}-\mathrm{W}(\mathrm{V}) \geq \mathrm{I}$. The value of the waiting option $\mathrm{W}$ for values of $\mathrm{V}$ below $\mathrm{V}^{*}$ can be approximated by:

$\mathrm{W}(\mathrm{V}, \beta, \mathrm{I})=(\mathrm{I} /(\beta-1))^{1-\beta}(1 / \beta)^{\beta} \mathrm{V}^{\beta}$

where by dividing for I and expressing the value of the call as a ratio with respect to the investment cost:

$\mathrm{W} / \mathrm{I}=(1 /(\beta-1))^{\beta-1} \beta^{\beta}(\mathrm{V} / \mathrm{I})^{\beta}$

taking natural logarithms ${ }^{14}$ :

$\ln (\mathrm{W} / \mathrm{I})=-(\beta-1) \ln (\beta-1)+\beta \ln (\beta)+\beta \ln (\mathrm{V} / \mathrm{I})$

and differentiating with respect to $\beta$ :

$\mathrm{d} \ln \left(\frac{\mathrm{W}}{\mathrm{I}}\right)=\left[-\ln (\beta-1)-1+\ln (\beta)+1+\ln \left(\frac{\mathrm{V}}{\mathrm{I}}\right)\right] \mathrm{d} \beta$

we obtain:

$\frac{\mathrm{dW} / \mathrm{I}}{\mathrm{W} / \mathrm{I}}=[\ln (\mathrm{V} / \mathrm{I})+\ln (\beta /(\beta-1))] \mathrm{d} \beta$

and making use of (6):

$\frac{\partial \mathrm{W}}{\partial \beta}=\left[\ln \left(\mathrm{V} / \mathrm{V}^{*}\right)\right] \frac{\mathrm{W}}{\mathrm{I}}>0$

\footnotetext{
${ }^{13}$ Is straightforward to see that under no uncertainty (e.g. $\left.\sigma^{2}=0\right) \mathrm{W}$ would have no value, taking us back to the simple investment decision of investing when $\mathrm{V} \geq \mathrm{I}$.

${ }^{14}$ A monotonic transformation not affecting the sign of results.
} 
we get that the derivate is negative given that $V^{*}>V$, hence

$\frac{\partial(\mathrm{W} / \mathrm{I})}{\partial \sigma^{2}}>0$

we obtain that an increase in volatility (uncertainty) affects positively the value of the waiting option and increases $\mathrm{V}^{*}$, therefore delaying the investment decision and the accumulation of capital until the value of capital is high enough.

\subsection{A stylized dynamic model relating the rate of growth of the economy and the rate of return of market value of the stock of capital}

As I was mentioned before, the variable $\mathrm{q}$ drives the investing and disinvesting process, taking into account the option value, to help adjust the current stock of capital to the desired one in time ${ }^{15}$ :

$\mathrm{K}=\mathrm{K}(\mathrm{q})$

where

$\frac{\partial K}{\partial q}=K^{\prime}>0$

These relationships state that the stock of capital responds positively through the investment process to an increase in the value of the variable q. We define this variable $\mathrm{q}$ as positively related to the expected rate of growth of the output ${ }^{16}$ in the form:

$\mathrm{q}=\mathrm{q}\left(\mathrm{Q}^{\mathrm{e}}\right)^{17}$

\footnotetext{
${ }^{15}$ Appendix $\mathrm{C}$ shows evidence about the relationship between aggregate investment and performance of the stock market index for the argentinean economy.

${ }^{16}$ The basic notion is that with an optimal relation between output and stock of capital, any increase in the expected output makes necessary to increase the stock of capital, and given this adjustment does not occur instantaneously, the shadow price reflects the change until the investment process takes place.
} 
where $Q^{\mathrm{e}}$ represents the expected level of GDP. The function $\mathrm{q}$ has the following properties:

$$
\frac{\partial \mathrm{q}}{\partial \mathrm{Q}^{\mathrm{e}}}=\mathrm{q}^{\prime}>0
$$

and

$$
\frac{\partial^{2} \mathrm{q}}{\partial \mathrm{Q}^{\mathrm{e}^{2}}}=\mathrm{q}^{\prime \prime}>0
$$

We define the dynamics of change of the variable $Q^{e}$ through the following Brownian motion:

$\mathrm{dQ}^{\mathrm{e}}=\mu_{\mathrm{g}} \mathrm{Q}^{\mathrm{e}} \mathrm{dt}+\sigma_{\mathrm{g}} \mathrm{Q}^{\mathrm{e}} \mathrm{dz}$

where $\mu_{\mathrm{g}}$ represents the expected rate of growth of the output, $\sigma_{\mathrm{g}}$ represents the instantaneous volatility of the rate of growth and dz follows a Wiener process.

We can approximate in a "mean squares" sense the dynamics of q from the dynamics of $\mathrm{Q}^{\mathrm{e}}$ applying Ito's Lemma on equation (18), and making use of (19) and (20):

$\mathrm{dq}=\mathrm{q}^{\prime} \quad \mathrm{dQ}+1 / 2 \mathrm{q}^{\prime} \delta_{\mathrm{g}}^{2} \mathrm{Q}^{\mathrm{e} 2} \mathrm{dt}$

replacing $d^{e}{ }^{e}$ by (9) we get:

$\left.\mathrm{dq}=\mathrm{q}^{\prime} \mu_{\mathrm{g}} \mathrm{Q}^{\mathrm{e}} \mathrm{dt}+\sigma_{\mathrm{g}} \mathrm{Q}^{\mathrm{e}} \mathrm{dz}\right)+1 / 2 \mathrm{q}^{\prime} \sigma_{\mathrm{g}}^{2} \mathrm{Q}^{\mathrm{e} 2} \mathrm{dt}$

rearranging terms:

${ }^{17}$ To practical matters, a micro relation between growth and value of the stock of capital is shown in Appendix B where we obtain the relation:

$V=f(g)$

where we can derive conditions under which the expected value and the volatility of $\mathrm{V}$ are associated to the equivalent parameters of $\mathrm{g}$, and the investment decision process will compare this value with the installment cost I. 
$\mathrm{dq}=\left(\mathrm{q}^{\prime} \mu_{\mathrm{g}} \mathrm{Q}^{\mathrm{e}}+1 / 2 \mathrm{q}^{\prime} \delta_{\mathrm{g}}^{2} \mathrm{Q}^{\mathrm{e} 2}\right) \mathrm{dt}+\mathrm{q}^{\prime} \sigma_{\mathrm{g}} \mathrm{Q}^{\mathrm{e}} \mathrm{dz}$

where it can be observed the drift of the process for dq,

$\mu_{\mathrm{q}}=\left(\mathrm{q}^{\prime} \mu_{\mathrm{g}} \mathrm{Q}^{\mathrm{e}}+1 / 2 \mathrm{q}^{\prime} \sigma_{\mathrm{g}}^{2} \mathrm{Q}^{\mathrm{e} 2}\right)$

and its instantaneous deviation

$\sigma_{\mathrm{q}}=\mathrm{q}^{\prime} \sigma_{\mathrm{g}} \mathrm{Q}^{\mathrm{e}}$

obtaining the process

$\mathrm{dq}=\mu_{\mathrm{q}} \mathrm{dt}+\sigma_{\mathrm{q}} \mathrm{dz}$

where it is relevant that volatility of variable $\mathrm{q}$ is positively related to the volatility of the expected rate of growth of output according to (26):

$\sigma_{\mathrm{q}}=\mathrm{f}\left(\sigma_{\mathrm{g}}\right)$

with

$$
\frac{\partial \sigma_{q}}{\partial \sigma_{g}}>0
$$

The development of equations shows that the volatility of the expected rate of growth affects in a positively way the volatility of the shadow price of capital ${ }^{18}$. Having found a dynamic process for the variable $q_{t}$, is valid now to propose a process for the variable $V_{t}$ according to equation (3) where by completely differentiating with respect to q through the use of Ito's Lemma, and getting rid of the sub index t, we obtain:

\footnotetext{
${ }^{18}$ We should not forget that all results are valid in a "mean squares" sense.
} 
$d V=V^{\prime} d q+1 / 2 V^{\prime \prime} \sigma_{q}^{2} d t$

where by replacing the first and second derivatives of $\mathrm{V}$ with respect to q:

$d V=\left[K+q K^{\prime}\right] d q+1 / 2\left[2 K^{\prime}+q K_{q}^{\prime \prime}\right]^{2} d t$

replacing dq according to (27) and rearranging terms:

$d V=\left[\left(K+q K^{\prime} \not \iota_{q}+1 / 2\left(2 K^{\prime}+q K^{\prime \prime} \phi_{q}^{2}\right] d t+\left[K+q K^{\prime} \phi_{q} d z\right.\right.\right.$

diving both sides by $\mathrm{V}$ :

$\frac{\mathrm{dV}}{\mathrm{V}}=\left[\left(\frac{\mathrm{K}}{\mathrm{V}}+\mathrm{q} \frac{1}{\mathrm{~V}} \mathrm{~K}^{\prime}\right) \mu_{\mathrm{q}}+\frac{1}{2}\left(2 \frac{\mathrm{K}^{\prime}}{\mathrm{V}}+\mathrm{q} \frac{\mathrm{K}^{\prime \prime}}{\mathrm{V}}\right) \sigma_{\mathrm{q}}{ }^{2}\right] \mathrm{dt}+\left(\frac{\mathrm{K}}{\mathrm{V}}+\mathrm{q} \frac{1}{\mathrm{~V}} \mathrm{~K}^{\prime}\right) \sigma_{\mathrm{q}} \mathrm{dz}$

and replacing $\mathrm{q}=\mathrm{V} / \mathrm{K}$ according to (3) we get:

$\frac{\mathrm{dV}}{\mathrm{V}}=\left[\left(\frac{1}{\mathrm{q}}+\frac{\mathrm{K}^{\prime}}{\mathrm{K}}\right) \mu_{\mathrm{q}}+\frac{1}{2}\left(2 \frac{\mathrm{K}^{\prime}}{\mathrm{qK}}+\frac{\mathrm{K}^{\prime \prime}}{\mathrm{K}}\right) \sigma_{\mathrm{q}}^{2}\right] \mathrm{dt}+\left(\frac{1}{\mathrm{q}}+\frac{\mathrm{K}^{\prime}}{\mathrm{K}} \cdot\right) \sigma_{\mathrm{q}} \mathrm{dz}$

Intuitively the first term (drift) of equation (34) states that the rate of change in the value of the stock of capital is composed of two effects: the price effect coming from a change in expectations which can be defined as the short term effect; and the quantity or volume effect which represents the change in the stock coming from the investment process, which can de defined as the long term effect.

Making use of the dynamic equation (27) derived for $\mathrm{dq}$ in terms of the parameters derived in (25) and (26) of the original process (23), we obtain:

$$
\begin{aligned}
& \frac{\mathrm{dV}}{\mathrm{V}}=\left[\left(\frac{1}{\mathrm{q}}+\frac{\mathrm{K}^{\prime}}{\mathrm{K}}\right)\left(\mathrm{q}^{\prime} \mu_{\mathrm{g}} \mathrm{Q}^{\mathrm{e}}+\frac{1}{2} \mathrm{q}^{\prime \prime} \sigma_{\mathrm{g}}^{2} \mathrm{Q}^{\mathrm{e}^{2}}\right)+\frac{1}{2}\left(2 \frac{\mathrm{K}^{\prime}}{\mathrm{qK}}+\frac{\mathrm{K}^{\prime \prime}}{\mathrm{K}}\right)\left(\mathrm{q}^{\prime} \sigma_{\mathrm{g}} \mathrm{Q}^{\mathrm{e}}\right)^{2}\right] \mathrm{dt} \\
& +\left(\frac{1}{\mathrm{q}}+\frac{\mathrm{K}^{\prime}}{\mathrm{K}}\right) \mathrm{q}^{\prime} \sigma_{\mathrm{g}} \mathrm{Q}^{\mathrm{e}} \mathrm{dz}
\end{aligned}
$$


where we observe that the first term in the dynamic process for the variable Vt represents the drift of the stochastic process, while the second term shows the volatility:

$\alpha=\left(\frac{1}{\mathrm{q}}+\frac{\mathrm{K}^{\prime}}{\mathrm{K}}\right)\left(\mathrm{q}^{\prime} \mu_{\mathrm{g}} \mathrm{Q}^{\mathrm{e}}+\frac{1}{2} \mathrm{q}^{\prime \prime} \sigma_{\mathrm{g}}{ }^{2} \mathrm{Q}^{\mathrm{e}^{2}}\right)+\frac{1}{2}\left(2 \frac{\mathrm{K}^{\prime}}{\mathrm{qK}}+\frac{\mathrm{K}^{\prime \prime}}{\mathrm{K}}\right)\left(\mathrm{q}^{\prime} \sigma_{\mathrm{g}} \mathrm{Q}^{\mathrm{e}}\right)^{2}$

and

$\sigma=\left(\frac{1}{\mathrm{q}}+\frac{\mathrm{K}^{\prime}}{\mathrm{K}}\right)^{\prime} \mathrm{q}^{\prime} \sigma_{\mathrm{g}} \mathrm{Q}^{\mathrm{e}}$

or in a similar way in terms of he parameters of the process for q:

$\alpha=\left(\frac{1}{\mathrm{q}}+\frac{\mathrm{K}^{\prime}}{\mathrm{K}}\right) \mu_{\mathrm{q}}+\frac{1}{2}\left(2 \frac{\mathrm{K}^{\prime}}{\mathrm{qK}}+\frac{\mathrm{K}^{\prime \prime}}{\mathrm{K}}\right)\left(\sigma_{\mathrm{q}} \mathrm{Q}^{\mathrm{e}}\right)^{2}$

and

$\sigma=\left[\frac{1}{q}+\frac{K^{\prime}}{K}\right] \sigma_{q}$

respectively, where the dynamic of $\mathrm{V}$ according to (35) can be expressed as:

$\frac{\mathrm{dV}}{\mathrm{V}}=\alpha \mathrm{dt}+\sigma \mathrm{dz}$

representing the usual stochastic process used in modeling the value of an underlying asset in the context of options, which was our starting point in equation (4).

\subsection{A quantitative analysis between volatility of the rate of growth of output and volatility of returns on assets}

According to results obtained before, a higher level of volatility in the rate of growth of output is consistent with a higher level of volatility in the market value of the stock of 
capital, shown in the dynamic of equation (34). The purpose of the present point is to check evidence of this, so we take data series from 1992 to 2001 (subject to availability) of stock index prices (as a proxy of the market value of capital ${ }^{19}$ ) from the data base Bloomberg, and of GDP levels (from IMF and World Bank) in dollar terms for a set of 41 countries $^{20}$ (see Appendix A); with these data we proceed to calculate the annual rate of change obtaining two series running from 1993 to 2001 (one observation is lost). We calculate the standard deviation for both the rate of change in GDP and index prices for all the countries, obtaining 41 combinations of volatility of rate of growth of GDP and stock price indexes. The following graph helps picture the date, having added a trend line to better depict the relationship; we can see a positive relation.

\section{Graph 4 Relationship between annual volatility of rate of growth of GDP and stock price indexes (in current U\$S 1993-2001)}

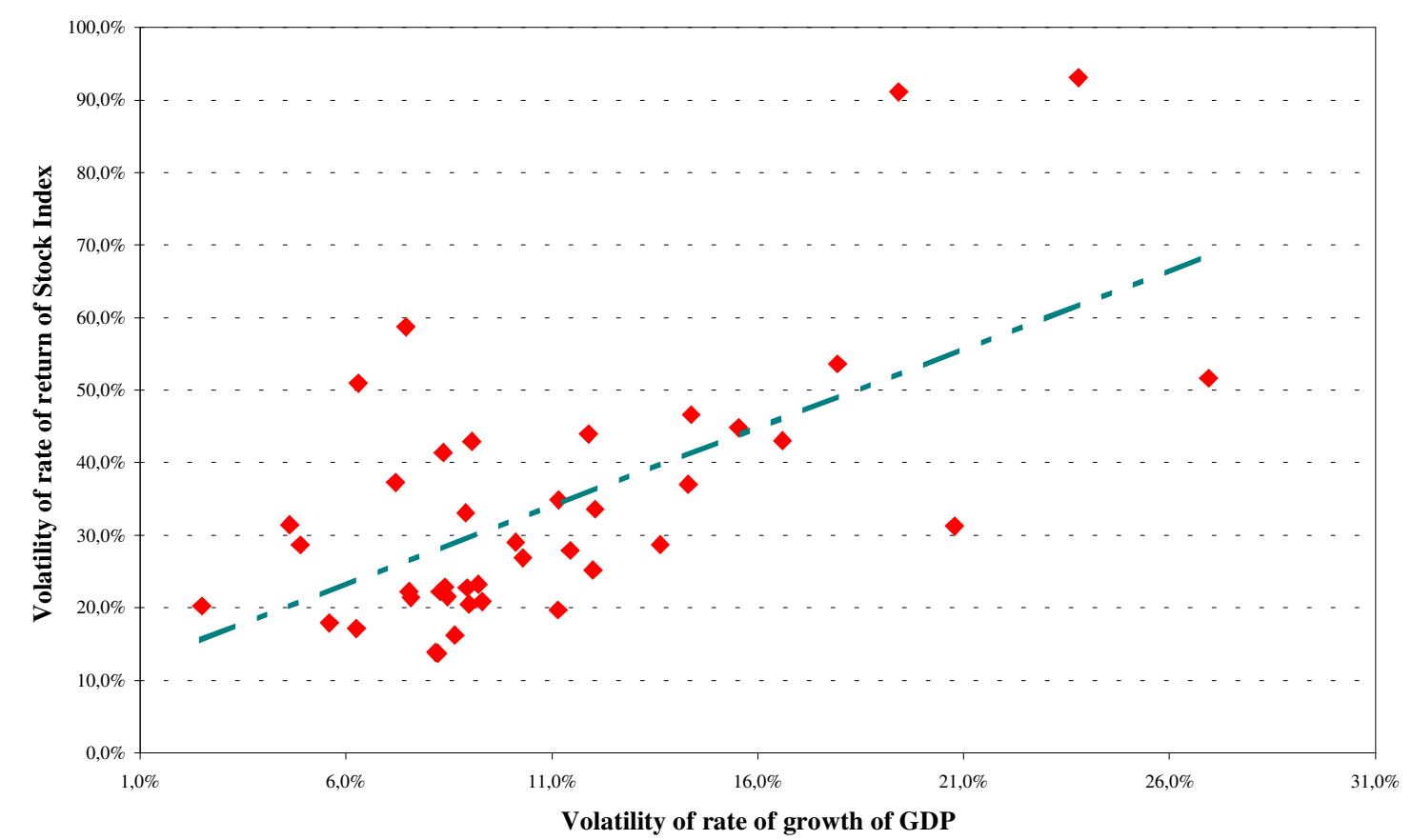

With the data we proceed to run a regression in the form ${ }^{21}$ :

$\sigma_{\text {Index return }}=\alpha+\beta_{1} \sigma_{\mathrm{GDP} \text { rate }}+\beta_{2} \mathrm{D}_{\mathrm{G}-7 / \text { Europe }}+\varepsilon$

\footnotetext{
${ }^{19}$ It is an imperfect approximation but has the good point of being market values..

${ }^{20}$ We should point out that these are realized rates of growth (instead of expected rates of growth used before.

${ }^{21}$ To the purpose of the definition of the model, we ran many regressions, including taking the nominal exchange rate for each country as a repressor (because data is expressed in current dollar), and also grouping countries in Latin America and Asia in a different way, but results proved not statistically significant at a $95 \%$ level.
} 
where the coefficient $\beta_{1}$ represents the sensitivity of the volatility of the Index return to a change in the volatility of the rate of growth of GDP, while $\beta_{2}$ is associated to a dummy variable that adopts the value 1 if the economy belongs the a certain group of countries (industrialized countries plus countries of Europe, Australia and New Zealand) and 0 otherwise. The following table shows the regression results ${ }^{22}$ :

Table 2 WLS Regression results

Weighted Least Squares

\begin{tabular}{lrrr}
\hline Variable & Coefficient & t-Statistic & \multicolumn{2}{c}{ Prob. } \\
\hline Constant & 0,32618 & 8,07435 & 0,0000 \\
Volatility GDP & 0,84182 & 2,33330 & 0,0250 \\
Dummy & $-0,19981$ & $-6,20218$ & 0,0000
\end{tabular}

Unweighted Statistics

R squared* $\quad 0,532452$

Adjusted R squared* $\quad 0,507844$

Observaciones: 41

* unweighted statistics

F-statistic Weighted Model $\quad 1,044933$ Probability $\quad 0,384133$

where coefficients have been corrected for heteroskedasticity. The squared correlation coefficient $\left(\mathrm{R}^{2}\right)$ is above $50 \%$, the coefficients are statistically significant and have the expected signs, giving rise to the following relationship ${ }^{23}$ :

$\sigma_{\text {Index return }}=0.32618+0.84182 \sigma_{\mathrm{GDP} \text { rate }}-0.19981 \mathrm{D}_{\mathrm{G}-7 / \text { Europe }}+\mathrm{e}$

Bringing up equation (40), the volatility in the rate of growth of the output is statistically significant to explain the volatility in the Index return, backing our previous results; there is also a significant difference between groups of countries, more developed countries tend to have lower levels of volatility in their index returns. The

\footnotetext{
${ }^{22}$ The White test rejected the homoskedasticity hypothesis, so we proceeded to correct using a weighted matrix. To the purpose of the calculation of the weighting matrix we estimated the covariance matrix as a function of the forecasted value for the dependant variable in the form:

variance $=$ constant + forecasted value of dependant variable + squared forecasted value of dependant variable. I thank comments of Santiago Avellaneda in this matter.

${ }^{23}$ The direction of causality follows the results obtained in the previous point. It is worth mentioning that we ran a causality test with the data (Granger test) and the results showed causality in both senses.
} 
results give initial empirical support to the propositions developed before ${ }^{24}$ so it stems that the volatility $\sigma$ is according equations (26) and (37) positively related with the volatility of the expected rate of growth of the economy, where a higher volatility in the rate of growth conveys a higher volatility in the value of the underling asset.

Making use of these results and according to a standard model of real options, we have seen that a higher level of volatility or uncertainty in the value of the stock of capital or underlying assets (coming from a higher level of volatility in the expected rate of growth) increases the value of the waiting option $\mathrm{W}(\mathrm{V})$ associated to the investment decision $\mathrm{V} \geq \mathrm{I}+\mathrm{W}(\mathrm{V})$, which in turn means that the value of the stock of capital $\mathrm{V}$ (or its ratio with respect to the installment cost I measured by the magnitude q) must reach higher values to trigger investments and hence justify killing the waiting option (or lower prices in the case abandonment decision), which delays the investment process and hence the formation of stock of capital. The outcome is that V (or alternatively $\mathrm{q}$ ) fluctuates up and down without triggering investment or abandonment, as it would do if the economy was more certain. The results obtained in these derivations help to link the volatility of the rate pf growth of output to the investment process and therefore to the accumulation of capital. According to this, in an environment of high volatility of the output (and extensively of the value of the stock of capital), better economic prospects do not translate automatically into investments, and will have different effects whether the economy is of low or high volatility; in the first case it may trigger investment, while in he second not (unless the expected rate of growth is high enough so to compensate). Higher level of volatility in the output (which negatively affects investment I by increasing the value of the waiting option $\mathrm{W}(\mathrm{V})$ ) would have to be compensated with a higher expected rate of growth (which increases the value V); if that was not the case, the investment process will be delayed and so economic development. Economies that show high levels of uncertainty in their rates of growth will have to consistently grow more to attract investment and increase their stock of capital or alternatively reduce fluctuations by appropriate economic policies which may include more resiliency to external shocks.

\footnotetext{
${ }^{24}$ We should take into account that data is measured in current dollar terms, with may have consequences in the case of sudden changes in the real exchange rate of a country, which may be more unstable in emerging markets, though the variable nominal exchange rate revealed itself as not significant. However, running a regression of the dependant variable with respect to the volatility of the real rate of growth of
} 


\section{The use of debt instruments in highly volatile economies}

In the previous section we developed considerations regarding the effects that high levels of volatility in the rate of growth of GDP may delay investments, accumulation of capital and therefore economic growth. The present section continues the line of analyzing the consequences of high volatility of output, now on the architecture of the financial system and on the use of financial instruments.

As we saw in the introduction, the optimal use of financial instruments is subject of formal study since the paper by Modigliani and Miller (1958). Even though the literature regards the analysis of financing at the corporate level, it is not less significant that economies as a whole tend to be affected by the use of different type of financial contracts (Bernanke and Gertler 1989 and 1990 and others already quoted in the introduction). This literature shares the study of the financing activity in the aggregate, which will be the line of research followed in the present section by means of application of tools of real options and contingent claims analysis, discussing the more suitable financial contracts for economies showing high level of volatility in their output. As a reference of this approach, we can quote the work of Gray, Merton et. al. (2003).

\subsection{Macroeconomic financing structure}

We continue analyzing an economy with aggregate output $\mathrm{Q}_{t}$ as function of capital and other resources recalling the relation ship (1):

$\mathrm{Q}_{\mathrm{t}}=\mathrm{f}\left(\mathrm{K}_{\mathrm{t}-1}, \Phi\right)$

The level of capital should be consistent with accumulated savings, where the macroeconomics structure of financing relates the sources of capital with uses or applications ${ }^{25}$ :

GDP, the coefficient is statistically significant and positive. Another caveat comes from the fact that some markets are more liquid than others, and we are not adjusting for that fact.

${ }^{25}$ See any macroeconomic text like Sachs and Larraín (1994). 
$\mathrm{K}_{\mathrm{t}-1}=\sum_{0}^{\mathrm{t}-1} \mathrm{~S}_{\mathrm{i}}=\mathrm{SA}$

where SA represents accumulated saving. The increase in the stock of capital comes in the form of investment, which in turn has to be financed by a flow of savings:

$I_{t}=K_{t}-K_{t-1}=S a_{t}$

where $\mathrm{Sa}_{\mathrm{t}}$ represents the aggregate flow of savings used to finance the investment per unit of time. The investment-savings interaction takes place through the use of internal or external capital markets ${ }^{26}$ or financial intermediation. In an open economy with a government sector, the amount of internal saving can differ from the investment needs because the gap is filled with the flow of external capital or savings; internal saving can also be decomposed into private and public internal saving because of the action of the government. This scheme allows us to define the financing equation of an economy:

- households and firms (private saving labeled SP)

- public sector (fiscal saving labeled SG)

- $\quad$ external sector (external flow of capital labeled SE)

from which we can propose the following relationship of sources and uses of funds in terms of aggregate financing or "balance sheet" approach:

$\mathrm{I}_{\mathrm{t}} \equiv \mathrm{Sp}_{\mathrm{t}}+\mathrm{Sg}_{\mathrm{t}}+\mathrm{Se}_{\mathrm{t}}$

where the sub index denotes the origin of savings. The relation is an accounting identity in terms of accumulated stocks:

$\mathrm{K}_{\mathrm{t}-1}=\sum_{0}^{\mathrm{t}-1} \mathrm{~S}_{\mathrm{i}}=\mathrm{SA}=\mathrm{SP}+\mathrm{SG}+\mathrm{SE}$

\footnotetext{
${ }^{26}$ We use the fact that there are investment operations not channelized through capital markets because firms or households make use of internal savings.
} 
where upper case letters stand for accumulated. Though we have real terms identities, we should bear in mind considerations exposed in the preceding section, where under the existence of capital market and being the stock of capital fixed at each moment of time, it cannot adjust instantaneously to a change in the flows of savings (due for example to a change in economic growth expectations or a flow of external saving), recalling relation $(3)$ :

$\mathrm{V}_{\mathrm{t}}=\mathrm{q}_{\mathrm{t}} * \mathrm{~K}_{\mathrm{t}-1}$

In this section we assume that variables follow the dynamics derived in the previous section with its associated results. According to equations (47) and (48), the level of aggregate savings or credit $^{27}$ finances the stock of capital in the form:

$\mathrm{V}_{\mathrm{t}}=\mathrm{q}_{\mathrm{t}} * \mathrm{~K}_{\mathrm{t}-1}=\mathrm{SP}+\mathrm{SG}+\mathrm{SE}$

while the flow is financed:

$\mathrm{q}_{\mathrm{t}}^{*} \mathrm{I}_{\mathrm{t}} \equiv \mathrm{Sp}_{\mathrm{t}}+\mathrm{Sg}_{\mathrm{t}}+\mathrm{Se}_{\mathrm{t}}$

These relationships allow to develop a very simple and tractable framework for the analysis of the structure of aggregate finance of the economy with sources and applications ${ }^{28}$ and also introducing a real "market price" of the stock of capital.

\subsection{Types of financial instruments}

Financing the stock of capital or investments can take place by means of two elementals contracts (which can be combined into more sophisticated ones):

- debt contract (defined by variable D)

- participation contract (defined by variable E)

\footnotetext{
${ }^{27}$ We do not take into account any kind of financial leverage, implied by the monetary multiplier for example.

${ }^{28}$ The "balance sheet" approach makes much more tractable the analysis in the aggregate.
} 
by which savings are channelized to investment. From this, and making use of equation (49) aggregate financing takes place under contracts D or E:

$\mathrm{V}_{\mathrm{t}}=\mathrm{q} * \mathrm{~K}_{\mathrm{t}-1}=\mathrm{SP}+\mathrm{SG}+\mathrm{SE}=\mathrm{E}+\mathrm{D}$

where E represents the stock of capital financed with equity contracts and D the remaining financed with debt contracts. In terms of flows, the identity can be expressed as:

$\mathrm{q}(\mathrm{g}) * \mathrm{I}_{\mathrm{t}} \equiv \mathrm{Sp}_{\mathrm{t}}+\mathrm{Sg}_{\mathrm{t}}+\mathrm{Se}_{\mathrm{t}}=\mathrm{e}+\mathrm{d}$

where e is the amount of investment financed with equity (including reinvestment with retained funds), and d represents investment financed with debt. The main differences between the contracts are:

- Debt contracts have a predetermined rate of interest while equity contracts have not. Debt has a known maturity while equity has not.

- Debt holders have a privilege to collect their money under situations of financial stress while equity holders keep the residual income.

The debt contract has a maturity that we define as $\mathrm{T}$; at the end it has to be repaid, while in the meantime pays interests at a rate denoted by $\mathrm{r}$ (we can assume this is the risk free rate of interest). At the expiration of the contract (time T) two outcomes can occur: the amount of debt is repaid or not (a default situation). In a very simple analysis, the amount of debt will be repaid if the value of the collateral is greater than the face value of debt (e.g. $V \geq D^{29}$ ), it will not when the value of asset acting as collateral falls below the face value of debt, where the borrower exercises what it is know as the abandonment option in the literature (or his right to "walk out"). In formal terms, the payoff function at maturity time can be expressed as:

$\mathrm{B}=\operatorname{MIN}(\mathrm{D}, \mathrm{V})=\mathrm{B}=\mathrm{D}-\mathrm{MAX}(\mathrm{D}-\mathrm{V}, 0)$

\footnotetext{
${ }^{29} \mathrm{D}$ in this context may be interpreted as degree of indebtedness with single maturity.
} 
where $\mathrm{V}$ is the market value of capital or asset acting as collateral from (51), D is the face value of debt and B is the market value of debt, which amounts for the possibility of a default (e.g. situations where $\mathrm{V}<\mathrm{D}$ ). The difference between $\mathrm{D}$ and $\mathrm{B}$ is the value of the abandonment option which in turn depends on the value $\mathrm{V}$ among other variables. In a similar way, the payoff function for equity holders at time $\mathrm{T}$ will be:

$\mathrm{E}=\operatorname{MAX}(\mathrm{V}-\mathrm{D}, 0)$

From (53) and (54) we observe that realizations of the stochastic variable V decide the payoff of each contract at time T. Moreover, we can see the privilege of debt holders where under financial distress $(\mathrm{D}<\mathrm{V})$, collect the remaining assets, while equity holders receive nothing. Adding up $\mathrm{E}+\mathrm{B}$ we obtain the former value $\mathrm{V}$ :

$\mathrm{V} \equiv \mathrm{E}+\mathrm{B}$

From this identity, we can see that if the realization of $\mathrm{V}$ never falls below the value $\mathrm{D}$, the debt holder receives $\mathrm{D}$ in every state of the nature and the debt contract is risk free in this sense, but when there are states of the nature where $\mathrm{V}$ falls below $\mathrm{D}$, bondholders will get less than the face value of their bonds, which is accounted in advance in the market value of debt B. Again, the difference between D and B accounts for the value of the abandonment or default option denoted now P.

\subsection{Implications of the use of debt contracts in economies with high volatility}

The possibility of default in a debt contract and limited responsibility introduce an asymmetry in the payoff function, giving rise to put option. We can gain intuition by inspecting the following graph: 


\section{Graph 1 Effect of an increase in volatility of the underlying asset}

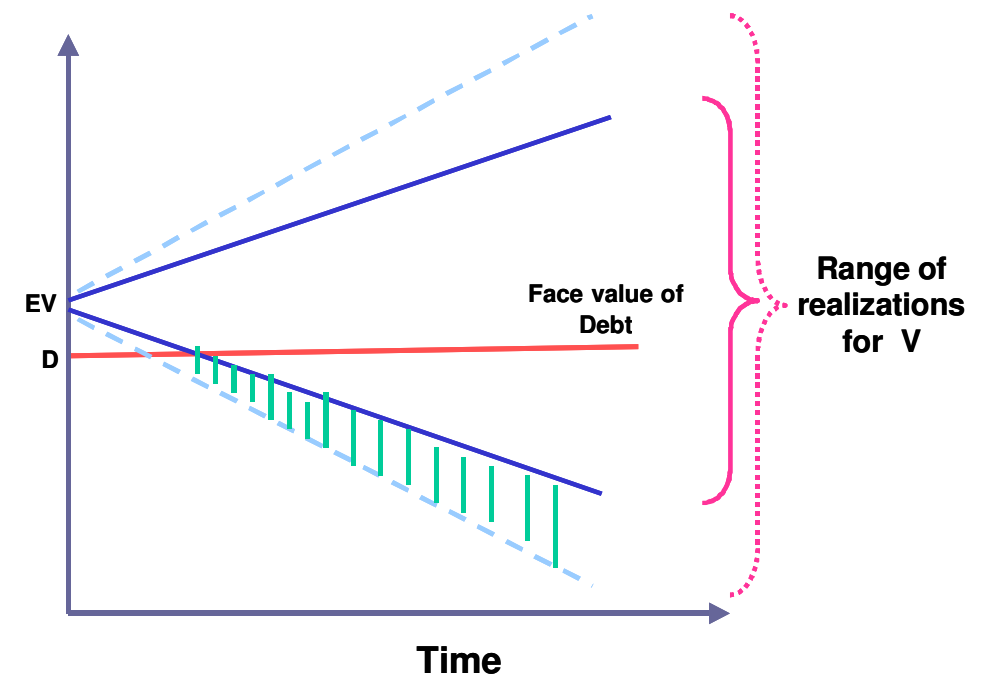

where a mean preserving increase in volatility of the value of the asset acting as collateral increases the value of the abandonment option associated, reduces the market value of the debt and increase the value of equity (known in the literature as expropriation by risk shifting). ${ }^{30}$. The increase in the value of the put option increases in turn the yield of return of those bonds to account to the higher risk coming from the possibility of default:

$y=r / B$

where $\mathrm{y}>\mathrm{r}$ because $\mathrm{B}<\mathrm{D}$, being the difference between the nominal rate of interest and the real yield:

$\lambda=\mathrm{y}-\mathrm{r}$

which can be seen as a default risk premium.

If we consider all variables constant, the higher the level of volatility, the higher the level of risk premium; in the same tense, the higher the level of debt related to V, the higher the risk premium component.

\footnotetext{
${ }^{30}$ This is a key reason for issuing "covenant" requirements in debt contracts.
} 


\subsection{Formal model for the put option}

Continuing with the development, we now show a model of interaction between volatility of asset value (which may arise according to the previous section from volatility of the output) and the level of indebtedness of the economy. Following Merton (1992) and others ${ }^{31}$ we derive a closed form solution for the value of the abandonment option by considering a perpetual put option ${ }^{32} \mathrm{P}$ with exercise price $\mathrm{D}$ (face value of debt) written on an underlying asset $\mathrm{V}$ (market value of the stock of capital in the economy) that follows a geometric Brownian motion of the form:

$\mathrm{dV}=\alpha \mathrm{Vdt}+\sigma \mathrm{Vdz}^{33}$

where $\sigma$ reflects the instantaneous volatility of $\mathrm{V}^{34}$. The value of the option $\mathrm{P}$ is derived in a standard way, and can be expressed as:

$$
\mathrm{P}(\mathrm{V})= \begin{cases}\left(\mathrm{D}-\mathrm{V}^{*}\right)\left(\mathrm{V}^{*} / \mathrm{V}\right)^{\beta} & \text { when } \mathrm{V} \geq \mathrm{V}^{*} \\ \mathrm{D}-\mathrm{V} & \text { when } \mathrm{V}<\mathrm{V}^{*}\end{cases}
$$

being $\mathrm{V}^{*}$ the value $\mathrm{V}$ at which becomes optimal to exercise the abandonment option given the value $\mathrm{D}$ :

$V^{*}=\beta /(1+\beta) D<D$

where $\beta$ is the positive root that solves the equation:

$\beta=\frac{-\left(\mathrm{r}-\sigma^{2} / 2\right)+\sqrt{\left(\mathrm{r}-\sigma^{2} / 2\right)^{2}+2 \mathrm{r} \sigma^{2}}}{\sigma^{2}}>1$

and

\footnotetext{
${ }^{31}$ See Ingersoll 1987 cap 19

${ }^{32}$ Perpetual put option means that the contract has no maturity, and can be exercised at any time; in the context of reality it could be seen as a debt contract with no roll over risk.

${ }^{33}$ The variables are consistent with the ones used in the previous section, save for the fact that here there are no dividends, but the model could be easily expanded to take into account that.
} 
$\beta=2 \mathrm{r} / \sigma^{2}$

where

$$
\frac{\partial \beta}{\partial \sigma^{2}}=\frac{-2 r}{\sigma^{4}}<0
$$

We can observe that given $\beta>1$ and $\beta /(1+\beta)<1$, the abandonment option takes place at a value $\mathrm{V}^{*}<\mathrm{D}$.

\subsection{Comparative statics}

We now develop on the impact of higher levels of volatility of the economy with respect to its financial structure. According to the previous point, the value of the abandonment option for values of $\mathrm{V}$ above $\mathrm{V}^{*}$ can be approximated by:

$\mathrm{P}(\mathrm{V}, \beta, \mathrm{D})=(\mathrm{D} /(1+\beta))^{1+\beta} \beta^{\beta} \mathrm{V}^{-\beta}$

where by dividing for $\mathrm{D}$ and expressing the value of the put as a ratio with respect to the face value of $\operatorname{debt}^{35}$ :

$\mathrm{P} / \mathrm{D}=(1 /(1+\beta))^{1+\beta} \beta^{\beta}(\mathrm{D} / \mathrm{V})^{\beta}$

taking natural logarithms ${ }^{36}$ :

$\ln (\mathrm{P} / \mathrm{D})=-(1+\beta) \ln (1+\beta)+\beta \ln (\beta)+\beta \ln (\mathrm{D} / \mathrm{V})$

and differentiating with respect to $\beta$ :

\footnotetext{
${ }^{34}$ According to the previous section, volatility of the returns of $\mathrm{V}$ could be partially explained by volatility in the expected rate of growth of the output of the investment.

${ }^{35}$ In this fashion the value of the put option is expressed as a percentage of loss with respect to the face value of debt, helping to better analyze the relationship expressed in (56) and (57).

${ }^{36}$ A monotonic transformation of the variables that does not affect the sign of the results.
} 
$d \ln \left(\frac{P}{D}\right)=\left[-\ln (1+\beta)-1+\ln (\beta)+1+\ln \left(\frac{D}{V}\right)\right] d \beta$

we obtain:

$\frac{\mathrm{dP} / \mathrm{D}}{\mathrm{P} / \mathrm{D}}=[\ln (\mathrm{D} / \mathrm{V})+\ln (\beta /(1+\beta))] \mathrm{d} \beta$

and making use of (60) we get that the derivate:

$\frac{\partial \mathrm{P}}{\partial \beta}=[\ln (\mathrm{V} * / \mathrm{V})] \frac{\mathrm{P}}{\mathrm{D}}<0$

is negative because $\mathrm{V}^{*}<\mathrm{V}$, and making use of (62) and (63) we obtain:

$\frac{\partial(\mathrm{P} / \mathrm{D})}{\partial \sigma^{2}}=[\ln (\mathrm{V} * / \mathrm{V})]\left(\frac{-2 \mathrm{r}}{\sigma^{4}}\right) \frac{\mathrm{P}}{\mathrm{D}}>0$

On the other hand, differentiating (66) with respect to D we obtain:

$\mathrm{d} \ln \left(\frac{\mathrm{P}}{\mathrm{D}}\right)=\beta\left(\frac{1}{\mathrm{D}}\right) \mathrm{dD}$

and:

$\frac{\partial(\mathrm{P} / \mathrm{D})}{\partial \mathrm{D}}=\left(\frac{\beta}{\mathrm{D}}\right)\left(\frac{\mathrm{P}}{\mathrm{D}}\right)>0$

Finally, by putting together the results shown in (70) and (72) we obtain a relationship between $d \sigma^{2}$ and $d D$ for $d(P / D)=0$ of the form: 
$\mathrm{dD}=\left.\frac{-\frac{\partial(\mathrm{P} / \mathrm{D})}{\partial \sigma^{2}}}{\frac{\partial(\mathrm{P} / \mathrm{D})}{\partial \mathrm{D}}} \mathrm{d} \sigma^{2}\right|_{\mathrm{d}(\mathrm{P} / \mathrm{D})=0}<0$

which in terms of the derivates, it implies

$\left.\frac{\mathrm{dD}}{\mathrm{d} \sigma^{2}}\right|_{\mathrm{d}(\mathrm{P} / \mathrm{D})=0}=\left.\frac{-[\ln (\mathrm{V} * / \mathrm{V})]\left(\frac{-2 \mathrm{r}}{\sigma^{4}}\right)}{\left(\frac{\beta}{\mathrm{D}}\right)}\right|_{\mathrm{dP}=0}<0$

The result arising in condition (74) is relevant, because it states that if we keep constant the value $\mathrm{V}$ of the underlying asset, any increase in its variance has to be balanced by a decrease in the variable $\mathrm{D}$ to keep constant the ratio of the value of the put option with respect to the face value of debt and hence the default risk premium.

For a better understanding of the process, we proceed with the following simulation; we normalize the value $\mathrm{V}$ at 100 , the risk free rate at $5 \%$, the face value of debt in 70 (showing financial leverage of $70 \%$, consistent with figures of aggregate leverage of companies in the Standard \& Poor' s 500 Index), and the volatility of $17.5 \%$ (as a proxy of asset value volatility, consistent with historical annual volatility of returns of stocks in the S\&P500 index ${ }^{37}$ ). For these figures, according to (65) the ratio of P/D (put value with respect to face value of debt) is $3.1 \%$. By increasing and decreasing the level of volatility keeping the value of $3.1 \%$ constant and following (74), we can see a clearly negative relationship between volatility and degree of financial leverage or indebtedness for a constant ratio $\mathrm{P} / \mathrm{D}$, so to keep the effective interest rate or yield constant according to equations s (56-57), any increase in volatility should be counterbalanced by a decrease on the degree of financial leverage. The next table and graph show the relationshiop for the figures chosen:

\footnotetext{
${ }^{37}$ This percentage of volatility clearly overstates the real volatility of asset returns, given it is a stock returns volatility, but should be forgiven for the purpose of the illustration
} 
Table 3 Combinations of volatility and financial leverage for a constant ratio P/D

\begin{tabular}{ccl}
\hline $\begin{array}{c}\text { Volatility of } \\
\text { Value of Capital } \\
\text { Stock }\end{array}$ & $\begin{array}{c}\text { Debt to Value } \\
\text { ratio }\end{array}$ & $\begin{array}{c}\text { Value of put to } \\
\text { Debt ratio }\end{array}$ \\
\hline $10,00 \%$ & $98,87 \%$ & \\
$12,50 \%$ & $91,85 \%$ & it is kept \\
$15,00 \%$ & $82,10 \%$ & constant to \\
\hline $\mathbf{1 7 , 5 0 \%}$ & $\mathbf{7 0 , 0 0 \%}$ & $\mathbf{3 , 1 \%}$ \\
\hline $20,00 \%$ & $58,27 \%$ & \\
$22,50 \%$ & $44,88 \%$ & \\
$25,00 \%$ & $33,29 \%$ & \\
$27,50 \%$ & $24,10 \%$ & \\
$30,00 \%$ & $16,14 \%$ & \\
$32,50 \%$ & $10,44 \%$ & \\
$35,00 \%$ & $6,47 \%$ & \\
$37,50 \%$ & $3,76 \%$ & \\
$40,00 \%$ & $2,09 \%$ & \\
$42,50 \%$ & $1,11 \%$ & \\
$45,00 \%$ & $0,56 \%$ & \\
$47,50 \%$ & $0,27 \%$ & \\
$50,00 \%$ & $0,12 \%$ & \\
& & \\
\end{tabular}

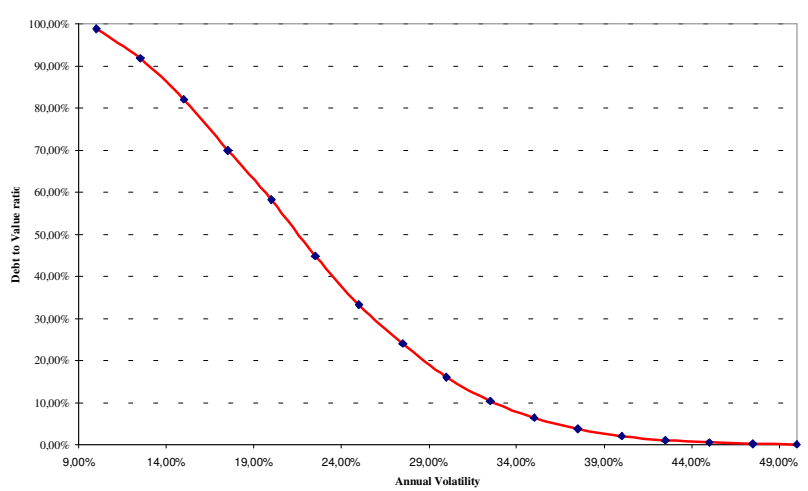

Following (63) and (69), an increase in the volatility of V increase in turn the value of the associated put option in the form:

$\mathrm{B} / \mathrm{D}=1-\mathrm{P} / \mathrm{D}$

with:

$\Delta(\mathrm{P} / \mathrm{D})>0$

and it follows:

$\Delta(\mathrm{B} / \mathrm{D})=-\Delta(\mathrm{P} / \mathrm{D})<0$

so $\Delta \lambda>0$ according to (57) rising the effective interest rate of the economy $(\Delta y>0)$ according to (56).Condition (74) says that to avoid the impact of volatility according (77) in the effective interest rate, a higher level of volatility should be balanced by a lower level of financial leverage (lower participation of $\mathrm{D}$ in the financing of $\mathrm{V}$ ) or what it is equivalent, a higher level of use of equity instruments to finance investment. 


\subsection{The effect of volatility it the architecture of macro financing}

The concepts developed so far shows that with all variables constant, the evidence of volatility in the returns of assets in the economy may require a deeper use of equity in the financing of the stock of capital $\mathrm{K}$ with market value $\mathrm{V}$ according to (74-77), to help maintain constant the effective cost of debt and reduce costs of financial distress, even more when the institutional environment is not very strong. More volatile economies should emphasize use of equity-liked instruments in the development of capital markets, which helps to minimize situations of financial distress in the presence of internal or external shocks. Coming back to the aggregate perspective, we can repeat relation (49) and obtain the following relationship between sources and applications of investment, and the type on instruments through which they take place:

$\mathrm{V}=\mathrm{q} \mathrm{K} \equiv \mathrm{SP}+\mathrm{SG}+\mathrm{SE}=\mathrm{E}+\mathrm{D}$

where D denotes the aggregate level of net debt (net indebtedness) with single duration $\mathrm{T}$ of the economy as a whole, and where the more intensive use of instruments $\mathrm{E}$ according to (55) implies use of more equity liked instruments in the financing of both the stock of capital and investment. The development of this kind of instruments conveys a lower aggregate risk of financial breach under negative states of the nature, adjusting through a change in prices instead of quantities of credit. This helps when the institutions are not well established (as it may happen in developing economies) and property rights are not properly acknowledged.

At this point is worth introducing considerations exposed in the previous section, where we observed evidence of correlation between the volatility of the rate of growth of the GDP and the volatility of the returns of a stock index (as a proxy of market value of capital). The evidence and the results obtained allow as to suggest that economies with high level of volatilities in their GDP's rates of growth should develop more equity oriented capital markets which let them better absorb volatility, providing with more giving flexibility and resiliency to the economy and hence help avoiding situations of jeopardy of financial contracts and rights, and financial distress arising from credit crunches $^{38}$.

\footnotetext{
${ }^{38}$ An interesting point not discussed comes from the crossed relationships of put options held by creditors arising from credit chains, where every borrower holds a put option, and where a breach in the credit
} 


\subsubsection{The effect of the Government behaviour}

The financing equation (78) incorporates the public sector as a source (or application) of funds) savings. The purpose of this point will be to explore how this situation affects the use or not of equity liked instruments in the light of the results shown before.

As a very simple approximation, we know that the level of savings of the public sector in terms of flows is given by:

$\mathrm{Sg}=\Delta \mathrm{D}=\mathrm{D}-\mathrm{D}_{-1} \equiv \mathrm{T}_{\mathrm{x}}-\mathrm{G}-\mathrm{r}_{\mathrm{G}} \mathrm{D}_{-1}$

where $\mathrm{D}_{-} \mathrm{D}_{-1}$ represents the change in the net assets position (real assets less real debt) of the Government, $\mathrm{G}$ is the level of aggregate expenditure for a given period of time; $T_{x}$ are revenues coming from taxes, and $r_{G} D_{-1}$ represents the rent in the net positions of assets of the public sector at an average rate $\mathrm{r}_{\mathrm{G}}$. The sources and applications of funds satisfy the intertemporal equilibrium constraint:

$\mathrm{V}_{\mathrm{G} 0}=\sum_{\mathrm{t}=0}^{\infty} \frac{\mathrm{G}_{\mathrm{t}}}{\left(1+\mathrm{r}_{\mathrm{G}}\right)^{\mathrm{t}}}=\sum_{\mathrm{t}=0}^{\infty} \frac{\mathrm{Tx}_{\mathrm{t}}}{\left(1+\mathrm{r}_{\mathrm{G}}\right)^{\mathrm{t}}}=\mathrm{V}_{\mathrm{Tx} 0}$

being the net asset position $\mathrm{D}$ the one that smoothes temporal changes and differences between revenues and expenditure, satisfying the consistency equation at every period of time $\mathrm{T}$ :

$\mathrm{D}_{\mathrm{GT}} \leq \sum_{\mathrm{t}=\mathrm{T}}^{\infty} \frac{\mathrm{Tx}_{\mathrm{t}}}{\left(1+\mathrm{r}_{\mathrm{G}}\right)^{\mathrm{t}}}-\sum_{\mathrm{t}=0}^{\infty} \frac{\mathrm{G}_{\mathrm{t}}}{\left(1+\mathrm{r}_{\mathrm{G}}\right)^{\mathrm{t}}}=\mathrm{V}_{\mathrm{TxT}}-\mathrm{V}_{\mathrm{GT}}$

Given that the public sector is not a private firm, it cannot issue shares of equity to finance its credit needs; it can only issue debt when needed. The problem may arise when the tax revenues are very tied to the business cycle ${ }^{39}$ :

$\mathrm{T}_{\mathrm{x}}=\mathrm{f}(\mathrm{Q})$

process may trigger successive exercise of put options by borrowers, increasing the possibility of a "credit crunch", and giving rise to potential "herd" behaviors and informational cascades. Gray, Merton et al (2003) provides an interesting work about this from the perspective of aggregate risk management. 
where Q stands for the GDP of the economy: a greater volatility in GDP can translate into a volatility of the tax revenues, and hence a higher volatility of the net present value of the tax revenues. ${ }^{40}\left(\mathrm{~V}_{\mathrm{Tx}}\right.$ according to (81)). We observe that equations (53-56) can be applied to the public sector, combined with equation (81):

$\mathrm{B}_{\mathrm{G}}=\mathrm{D}_{\mathrm{G}}-\mathrm{P}\left(\mathrm{V}_{\mathrm{G}}, \mathrm{D}_{\mathrm{G}}, \mathrm{T} ; \Omega\right)$

where

$\mathrm{E}_{\mathrm{G}}=\mathrm{V}_{\mathrm{G}}-\mathrm{B}_{\mathrm{G}}$

These expressions show that the yield the government pays to finance its credit needs is higher $\left(\mathrm{y}_{\mathrm{G}}>\mathrm{r}_{\mathrm{G}}\right.$ because of $\mathrm{B}_{\mathrm{G}}<\mathrm{D}_{\mathrm{G}}$ ) when there is volatility associated (keeping constant other variables) and generating costs to the whole economy through capital markets and competition for credit.

The concepts mentioned can bee seen for the argentinean case in the aftermath of the 2001 crises where the default risk premium for argentinean bonds (following equation (57) where $r$ stands for US risk free yields on bonds with similar characteristics and y stands for the yield of local bonds in U\$S) measured with respect to the Emerging Markets Bond Index (EMBI) by JP Morgan followed this pattern ${ }^{41}$ :

\footnotetext{
${ }^{39}$ Even more for some emerging economies with weak institutional environments where a fall in GDP can affect twice the tax income: directly reducing it and indirectly due to the presence of not declared business operations aimed to avoid paying taxes and saving the proceeds, given the scarcity of funds. ${ }^{40}$ A similar process to the one already presented.

${ }^{41}$ Tax income in Argentina was very tied to the business cycle, because the main source of taxes was IVA (value added tax), and because the degree of informal operations and lack of control. Now the structure has changed.
} 


\section{Graph 6 Default risk premium for argentinean bonds}

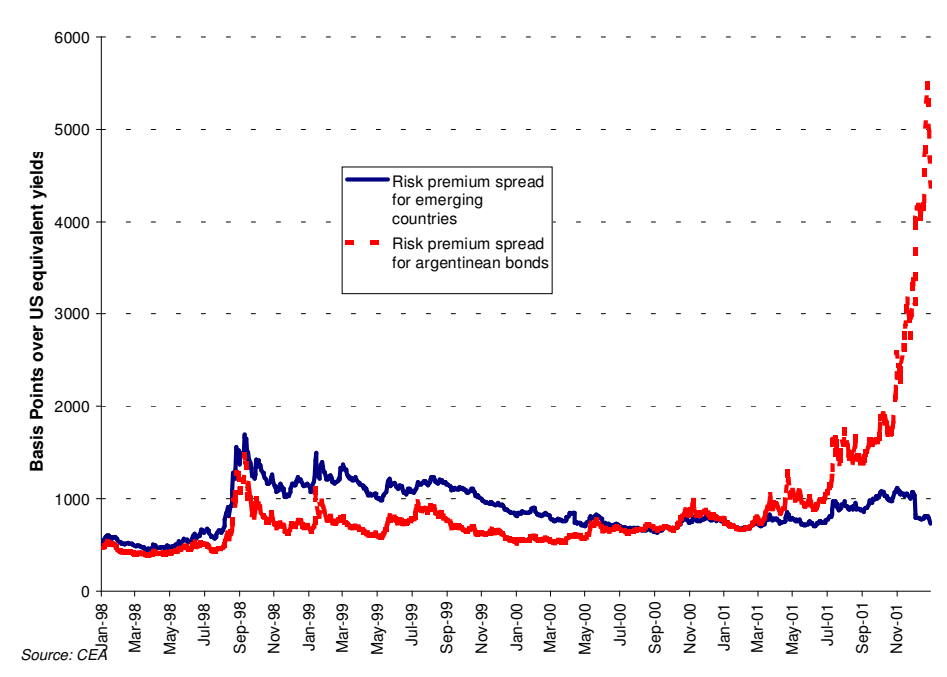

The propositions show that for high levels of uncertainty, the stock of government debt has to be lower in relation to GDP level in comparison with more stable economies. Even more, if government instruments can incorporate equity-liked features, like the recent post default issue of argentinean bonds, where there is a coupon whose payoff is tied to the evolution of the rate of growth of GDP, it would be highly advisable. In the same tense, it is better that government of highly volatile countries save more than their more industrialized counterparts, to better cushion sudden changes in the economic environment affecting the value of assets (as we may see in Section 5.3.2).

\subsubsection{The effect of external savings}

The level of external saving is associated to the current account SCC in the form:

$\mathrm{Se}=\mathrm{SCC} \equiv \Delta \mathrm{R}-\mathrm{SCK}$

where $\Delta \mathrm{R}$ is the change in the external net asset position and SCK is the net flow of external capital to the economy. According to previous results, policy makers of highly volatile economies should consider a deeper use of equity-liked instruments for external investment. Even more, equity-liked instruments would be less pernicious if there is a reversal in the flow of capital ("sudden stop"). However, the economy has also to defend itself by generating a cushion of internal savings (through the development of strong capital markets) that helps to resist a reversal in the flow of capital, keeping investment at reasonable levels according to equation (46) even more if the economy is 
volatile; otherwise it would become highly sensitive to international conditions in the credit markets and to the use of short term debt.

\section{Use of equity instruments and capital markets in Argentina ${ }^{42}$}

In this section we shall see evidence on the use of equity instruments.

\subsection{International use of equity instruments}

The following table shows a comparison for different countries of application of financial wealth:

Table 1 Distribution of financial wealth of European households

Bank deposits and cash Institutional investors Bonds - Individual Holdings Equities - Individual Holdings Source: GESF Mecon

\begin{tabular}{cc|cc|cc|cc}
\hline \multicolumn{2}{c|}{ United Kingdom } & \multicolumn{2}{|c|}{ Gremany } & \multicolumn{2}{c|}{ France } & \multicolumn{2}{c}{ Italy } \\
$\mathbf{1 9 9 0}$ & $\mathbf{2 0 0 0}$ & $\mathbf{1 9 9 0}$ & $\mathbf{2 0 0 0}$ & $\mathbf{1 9 9 0}$ & $\mathbf{2 0 0 0}$ & $\mathbf{1 9 9 0}$ & $\mathbf{2 0 0 0}$ \\
\hline $32,0 \%$ & $23,0 \%$ & $52,0 \%$ & $36,0 \%$ & $40,0 \%$ & $26,0 \%$ & $37,0 \%$ & $25,0 \%$ \\
$48,0 \%$ & $58,0 \%$ & $27,0 \%$ & $36,0 \%$ & $29,0 \%$ & $33,0 \%$ & $23,0 \%$ & $31,0 \%$ \\
$2,0 \%$ & $1,0 \%$ & $15,0 \%$ & $11,0 \%$ & $4,0 \%$ & $2,0 \%$ & $19,0 \%$ & $18,0 \%$ \\
$18,0 \%$ & $18,0 \%$ & $6,0 \%$ & $17,0 \%$ & $27,0 \%$ & $38,0 \%$ & $21,0 \%$ & $26,0 \%$
\end{tabular}

where we observe the high participation of equities in the total, also growing in time (the other one growing is the use of institutional investors). We can also see in the following graph the percentage of adult population holding equity:

\section{Graph $7 \%$ of adult population holding equity}

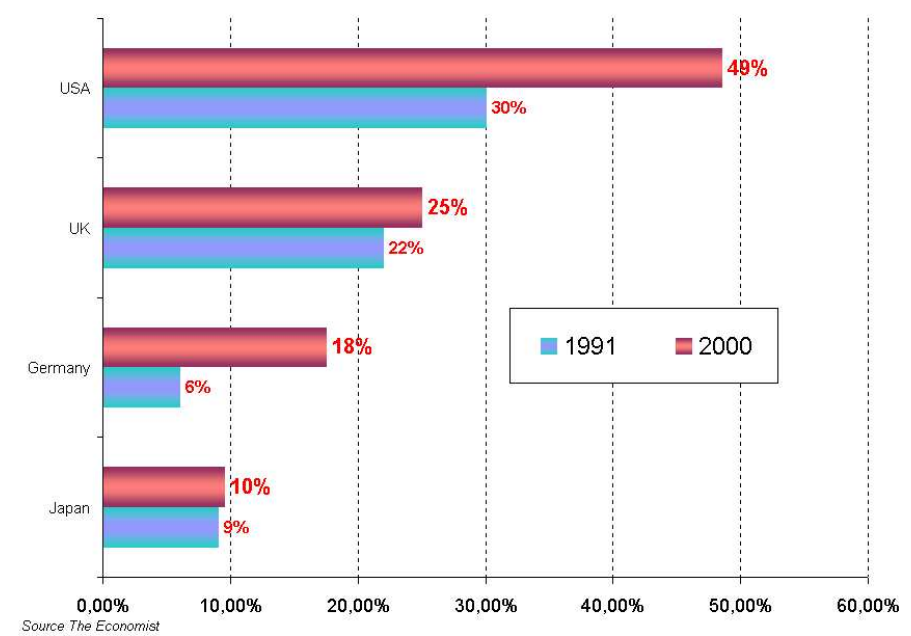

\footnotetext{
42 The analysis runs until the end of 2001, because it aims to provide evidence of how weak and vulnerable was the argentinean economy before the crises, and the low degree of use of equity when the "corralito" (frozen availability of bank deposits) was installed.
} 
which is high as well and growing. Even more, in the following table we can see the composition of the world stock of financial assets:

Table 5 World financial assets 1998 (in U\$S trillions)

\begin{tabular}{lc|c}
\cline { 2 - 3 } & Amount & in \% \\
\cline { 2 - 3 } Corporate Bonds & 10,0 & $12,5 \%$ \\
Government Bonds & 17,1 & $21,4 \%$ \\
\hline Equities & 28,6 & $35,7 \%$ \\
\hline Bank Deposits and cash & 24,3 & $30,4 \%$ \\
\hline Total & 80,0 \\
\hline
\end{tabular}

Source: The Economist s/IFC, SSB, MSCI, FMI, etc.

where equity represents approximately one third of the total amount ${ }^{43}$. The evidence let us see that international participation of equity instruments in the distribution of financial wealth is significant at a global scale.

\subsection{The use of financial instruments in Argentina during the ' 90}

It is interesting to see that the participation of equity at an international scale is growing. If we inspect the evolution of argentinean GDP:

Graph 4 Evolution of argentinean real GDP (1993 - 2005)

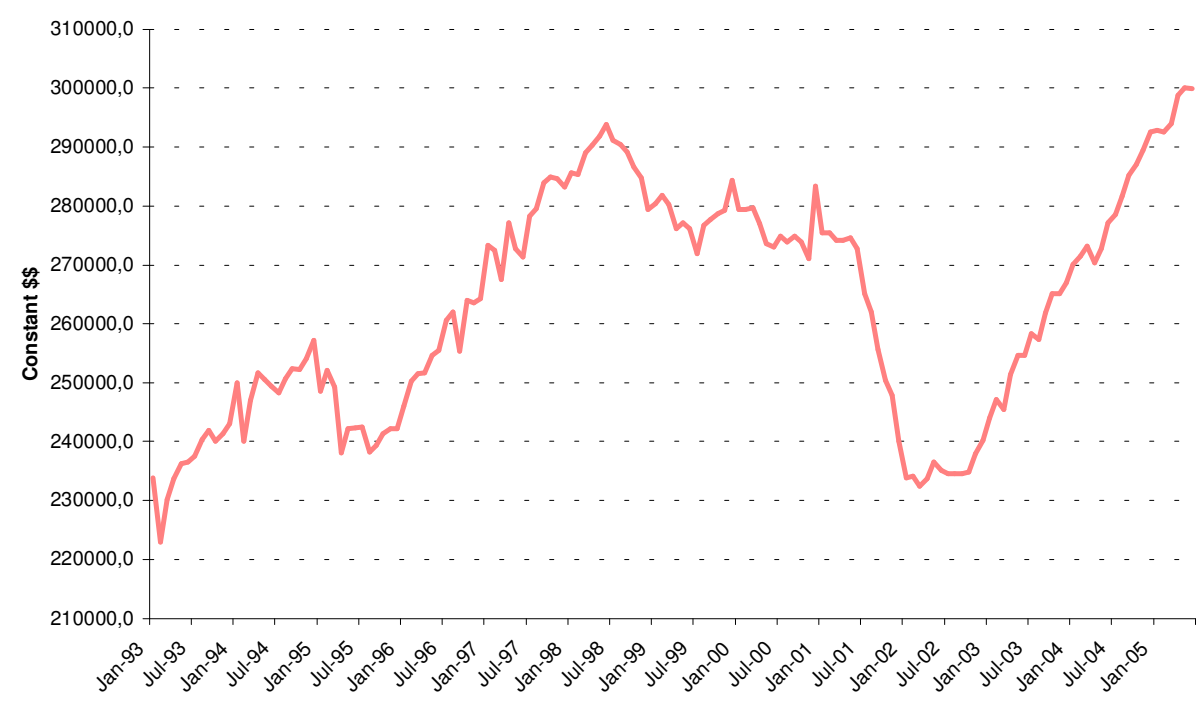

\footnotetext{
${ }^{43}$ Households accumulate both financial and no financial assets through their savings, representing the latter a significant share of the total, but not included here.
} 
and recalling the figures regarding the volatility of the rate of real growth, considerations arising from the previous sections would suggest that it was necessary to develop strong capital markets, fuelled with internal savings (both at a public and private sector) with prevalence of equity-liked financial instruments, that help better absorb uncertainty for a little and highly volatile economy. Now we shall inspect some evidence.

In the case of the argentinean economy, the evidence of participation of equity and internal savings (mainly by the public sector) did not show up ${ }^{44}$. The reason can be that argentinean capital markets are not well developed, and hence private savings are biased toward bank deposits (considerable less since the crisis), real estate and holding of external. Weitz and Bebczuk (2002) find that the stock of financial assets in June 2001 was distributed $52.1 \%$ in bank deposits and institutional investors, $10.5 \%$ in cash and securities (of which equity holdings represented $1.3 \%$ ) and $37.4 \%$ in external financial assets. To make things worse, though institutional investors had a high share of savings, most of their holdings were invested in bank deposits and government bonds as well, and the former were backed mainly by government bonds. Dapena (2003) estimates that the level of savings applied to the holdings of equity at the end of year 2001 was approximately:

Table 6 Percentage of financial assets invested in equity in 2001 in Argentina As $\%$ of total savings

Direct ownership of equity secirities $\quad 1,32 \%$ Indirect ownership of equities securities $\quad 3,77 \%$ Propiedad de activos financieros de participación

showing evidence of low participation of this kind of instruments in the financing activity, in comparison with international standards.

Another helpful element to understand the situation is to compare the market capitalization of listed companies with respect to the GDP level (in dollar terms ${ }^{45}$ ) at the end of December 2002 for different countries:

\footnotetext{
${ }^{44}$ Since default the government behavior has changed with respect to the history, focusing mainly in keeping fiscal numbers in good and healthy shape.

${ }^{45}$ Given this is a real o relative measure, it is difficult that considerations regarding over or under valuation of the real exchange rate may affect it.
} 
Table 7 Comparison of market capitalization to GDP ratios (2002)

\begin{tabular}{|c|c|c|c|c|c|c|c|}
\hline \multirow[b]{2}{*}{ (U\$S millions) } & & \multirow[b]{3}{*}{ EUROPE } & \multirow{3}{*}{\multicolumn{2}{|c|}{$\begin{array}{c}\text { Market } \\
\text { Capitalization } \\
\end{array}$}} & \multirow{3}{*}{ Ratio } \\
\hline & GDP & $\begin{array}{c}\text { Market } \\
\text { Capitalization } \\
\end{array}$ & Ratio & & & & \\
\hline INDUSTRIALIZED COUNTRIES (G-7) & & & & & & & \\
\hline United Kingdom & $1.671,60$ & $1.856,20$ & $111,04 \%$ & Switzerland & 298,7 & 547 & $183,13 \%$ \\
\hline United States & $10.480,80$ & $11.055,50$ & $105,48 \%$ & Luxemburg & 23,3 & 24,6 & $105,58 \%$ \\
\hline Canada & 737,6 & 570,2 & $77,30 \%$ & Finland & 145,5 & 138,8 & $95,40 \%$ \\
\hline Euronext & $2.452,80$ & $1.538,70$ & $62,73 \%$ & Sweden & 268,5 & 179,1 & $66,70 \%$ \\
\hline Italy & $1.310,80$ & 477,1 & $36,40 \%$ & Spain & 725,2 & 461,6 & $63,65 \%$ \\
\hline Germany & $2.198,30$ & 686 & $31,21 \%$ & Greece & 147,2 & 66 & $44,84 \%$ \\
\hline \multirow[t]{3}{*}{ Average } & & & $85,85 \%$ & Ireland & 134,7 & 59,9 & $44,47 \%$ \\
\hline & & & & Denmark & 190,8 & 76,7 & $40,20 \%$ \\
\hline & & & & Malta & 4,2 & 1,4 & $33,33 \%$ \\
\hline ASIA - PACIFIC & & & & Norway & 218,6 & 68,1 & $31,15 \%$ \\
\hline Hong Kong & 161,5 & 463,1 & $286,75 \%$ & Slovenia & 23,9 & 5,6 & $23,43 \%$ \\
\hline Malaysia & 94,9 & 122,9 & $129,50 \%$ & Turkey & 167,5 & 34,2 & $20,42 \%$ \\
\hline Singapur & 89,3 & 101,5 & $113,66 \%$ & Hungary & 75 & 13 & $17,33 \%$ \\
\hline Taiwan & 280,1 & 261,3 & $93,29 \%$ & Austria & 227,4 & 33,6 & $14,78 \%$ \\
\hline Australia & 414,4 & 380,1 & $91,72 \%$ & Poland & 201,2 & 28,8 & $14,31 \%$ \\
\hline Japan & $4.178,70$ & $3.561,20$ & $85,22 \%$ & Average & & & $60,96 \%$ \\
\hline India & 478,5 & 242,8 & $50,74 \%$ & & & & \\
\hline Korea & 498,3 & 216,1 & $43,37 \%$ & & & & \\
\hline China & $1.237,20$ & 463,1 & $37,43 \%$ & LATIN AMERICA & & & \\
\hline Thailand & 126,3 & 45,4 & $35,95 \%$ & Chile & 64,2 & 49,8 & $77,57 \%$ \\
\hline New Zealand & 67 & 21,7 & $32,39 \%$ & Brazil & 389,3 & 121,6 & $31,24 \%$ \\
\hline Phillipines & 75,2 & 18,2 & $24,20 \%$ & Peru & 56,8 & 11,4 & $20,07 \%$ \\
\hline Indonesia & 180,3 & 30,1 & $16,69 \%$ & Argentina & 93,6 & 16,5 & $17,63 \%$ \\
\hline Sri Lanka & 16,2 & 1,7 & $10,49 \%$ & Mexico & 592,6 & 103,9 & $17,53 \%$ \\
\hline Average & & & $75,07 \%$ & Average & & & $25,34 \%$ \\
\hline
\end{tabular}

where we can see that with the exception of the Chilean market, the rest of LatinAmerican countries evidences low ratios, better seen in a per region analysis:

Graph 8 Average of market capitalization to GDP ratios (2002)

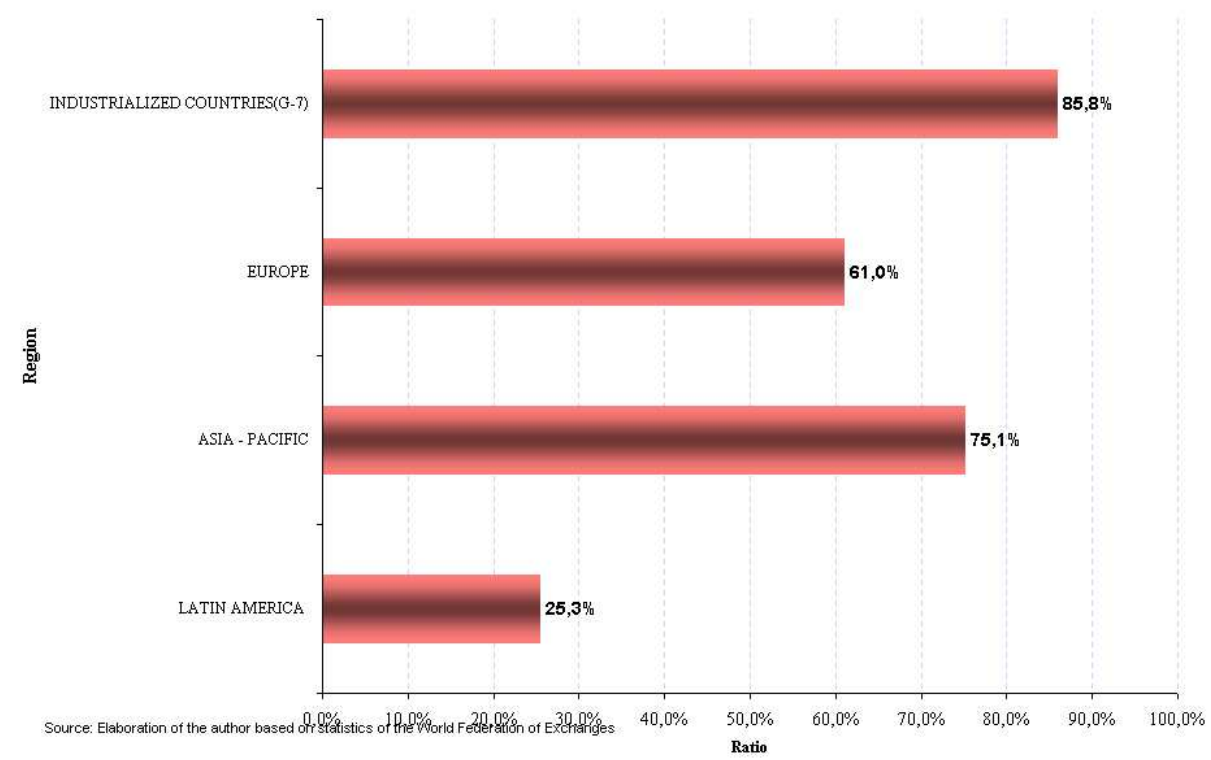

Another interesting data series is the amount of Initial Public Offerings made in the argentinean market. As it can be observed in the following graph, equity instruments in capital markets were not a very popular instrument of financing:. 
Graph 9 Initial public offerings in Argentina 1991-1999

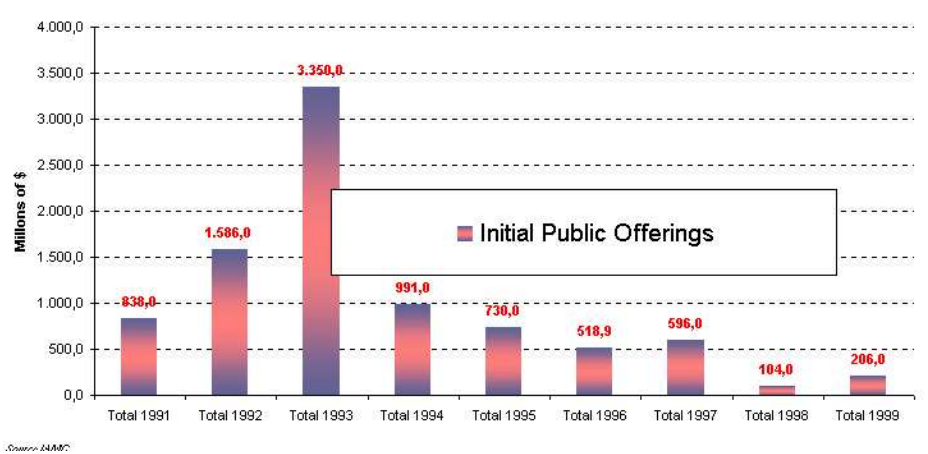

which affects also the number of listed companies:

Graph 10 Number of listed companies (1983-2001)

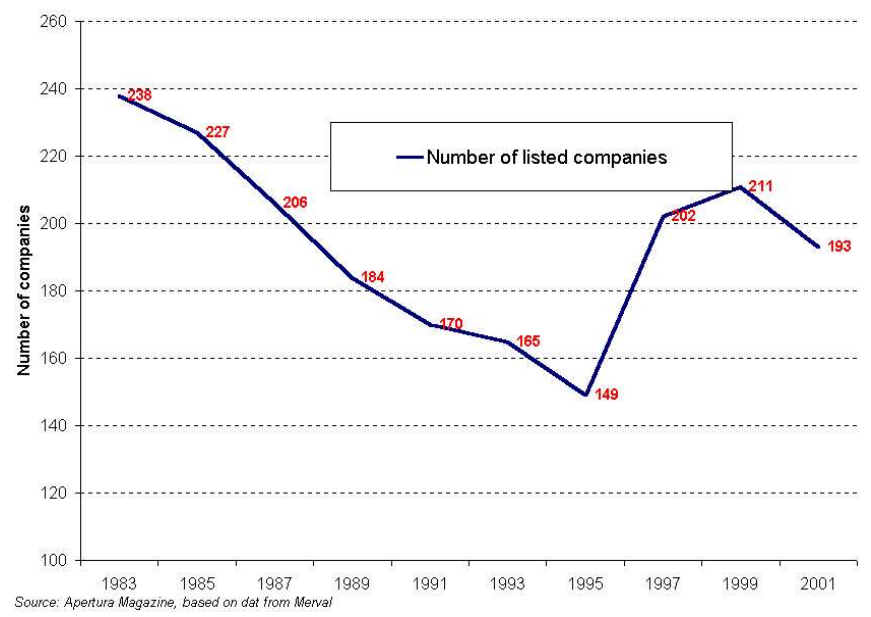

The evidence underlines the low degree of development of capital markets for equity instruments that Argentina (and Latin American in general) enjoys, though it is one of the countries (and region) with higher levels of volatility in its output.

\subsection{Possible explanations for the low use of capital markets and equity instruments} in Argentina

At the light of the considerations exposed before regarding the underdevelopment of capital markets and specially for equity financial instruments, we shall provide alternative explanations that helps better understand the situation. 


\subsubsection{Asymmetric information reasons, agency problems an corporate governance issues}

There is an extended literature aimed to explain why certain financial instruments are preferred over others. In this sense, when there is asymmetric information in capital markets where it becomes difficult to assess the real nature of different investment (which investment projects are really profitable and which not) in the sense of Akerloff (1970), the debt contract reveals as an efficient instrument of financing. Under this environment, economies facing asymmetric information in capital markets will tend to prefer debt instruments, which are more suitable for controlling such asymmetry in the information. A very significant point is that argentinean firms makes intensive use of retained earning as the main source of financing (see Dapena and Dapena 2003) which turns out to be the solution to two conditions of imperfections of capital markets, high volatility (requires the use of equity as was proposed before) and asymmetric information (use of own funds according to the Myers (1984) "pecking order"). This would not be an efficient outcome because investment according to equation (9) would have a ceiling limited to the own production of funds by firms, and diversification would not take full place.

Another explanation is proposed by Jensen and Meckling (1976) used by Bernanke and Gertler (1989), where in the presence of agency problems between majority shareholders and minority shareholders, and between shareholders and management, the debt contract reveals itself as better suited to cope with these problems ${ }^{46}$. However, the institutional framework is relevant, because the creditors should be able to get legal protection when they property rights are under threat.

\subsubsection{The effect of the Government}

We saw that according to equation (51) and (52), the public sector financial behavior may influence the availability of funds for investment purposes. There is no problem of sustaining a public sector deficit (negative public savings $\mathrm{Sg}<0$ ), when there are incoming flows of capital $(\mathrm{Se}>0)$ as we see it happened:

\footnotetext{
${ }^{46}$ It was mentioned in the introduction that there is literature like Bernanke and Gertler 1990) which suggest contingent repayment instruments as an interesting approach to risk management.
} 
Graph 12 Annual increase in sovereign debt and evolution of Real GDP and level of sovereign debt
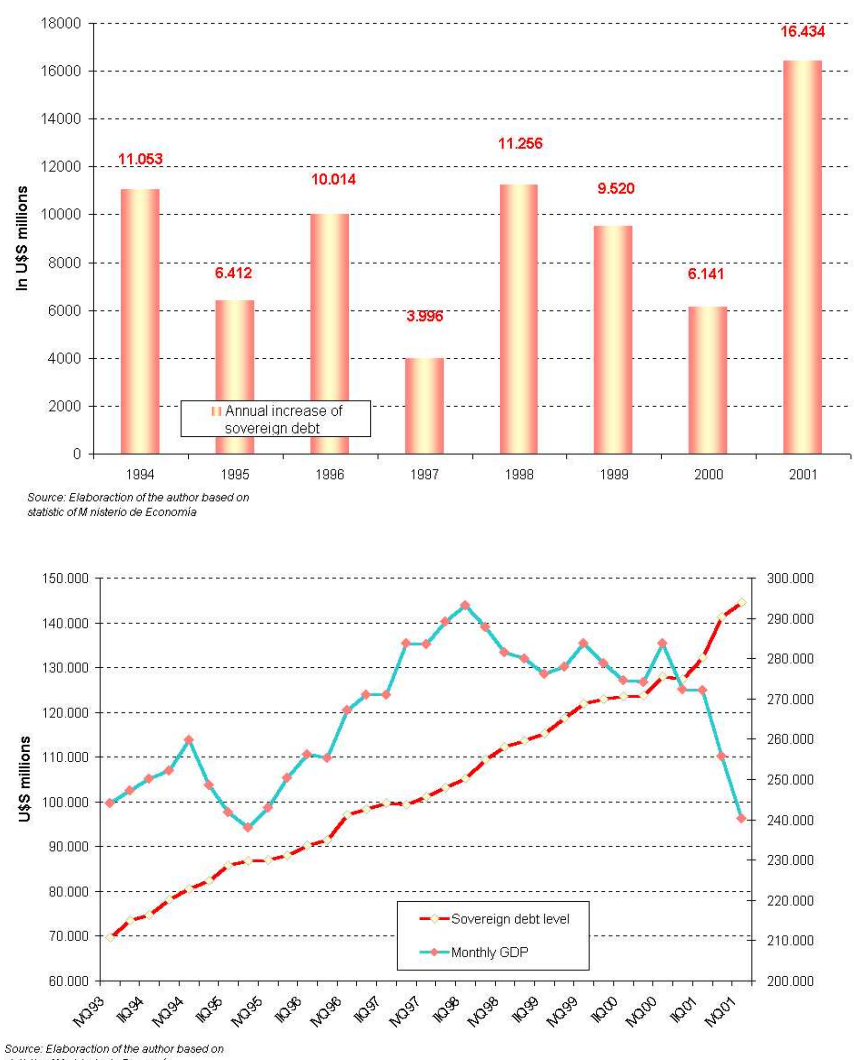

but in a situation of sudden reversal in the direction of external capital (e.g. Se becoming negative) keeping $\mathrm{Sg}$ negative may heavily affect investment as we can see in the following graph (where current account stands according to (85) for external savings, rights axis negative figure means external financing $\mathrm{Se}>0$ and viceversa):

\section{Graph 13 Internal Saving, Investment and Current Account as percentage of GDP}

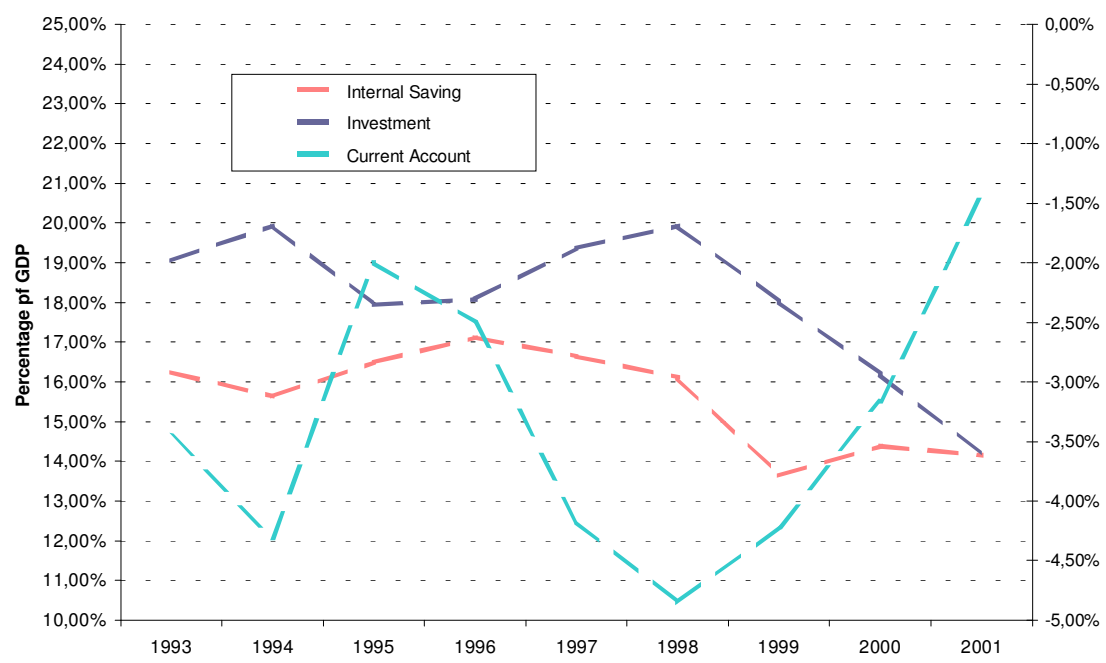


though the problem is that by tightening the fiscal policy we risk deepening a recession which puts the situation back to the one analyzed by Caballero and Krishnamurty (1998) where the economy lacks the necessary collateral to cope with the crises ${ }^{47}$. It is straightforward that strong capital markets may ask for a healthy fiscal policy, contributing to build internal saving and making the economy more resistant to shocks.

\subsubsection{The relevance of institutional investors}

The degree of indebtedness of the Argentinean government and its effect on capital markets, volatility and economic development is not a surprise because it has been the norm for Latin american countries. Now we shall see how this situation impacted in the behavior of institutional investors.

As we have already seen in Table 1, the relevance of institutional investors has grown internationally, so another possible explanation comes from the investment activity of them, and their portfolio investment ${ }^{48}$, therefore we will proceed to analyze the portfolio of investment of institutional investors in Argentina previous to the 2001/2002 crises. The following graph shows the dynamic of portfolio investment of Pension Funds $\left(\mathrm{AFJP}^{\prime} \mathrm{s}\right)$ :

\section{Graph 14 Investment portfolio of AFJPs 1995-2001 (October of each year)}

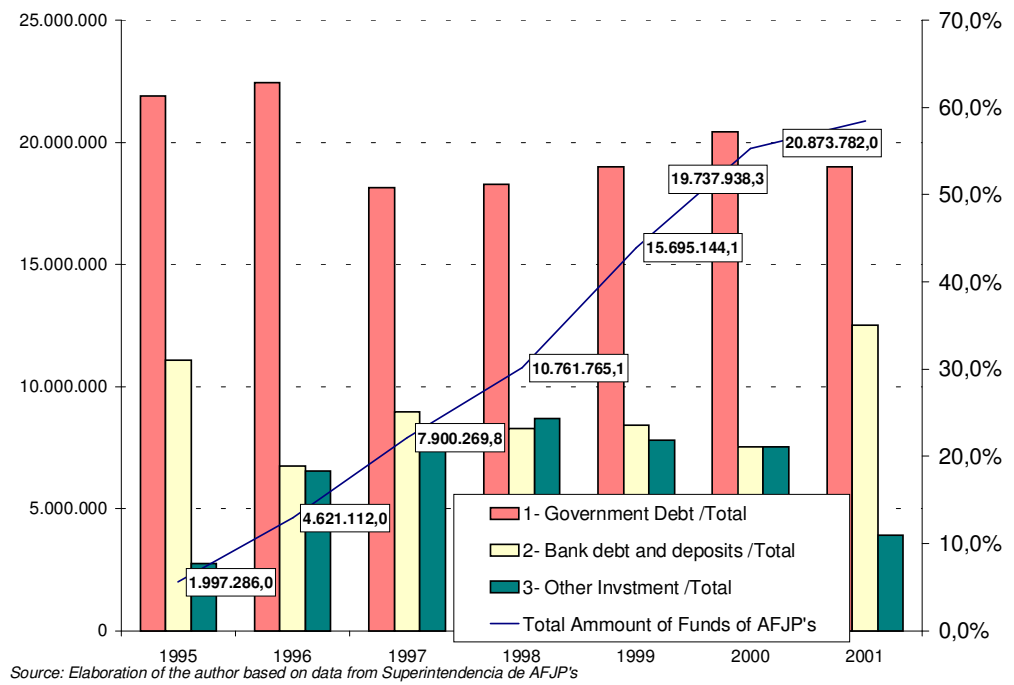

\footnotetext{
${ }^{47}$ There are also considerations regarding the exchange rate regime not considered here.
} 
and also insurance companies:

Graph 15 Investment portfolio of insurance companies 1999-2001

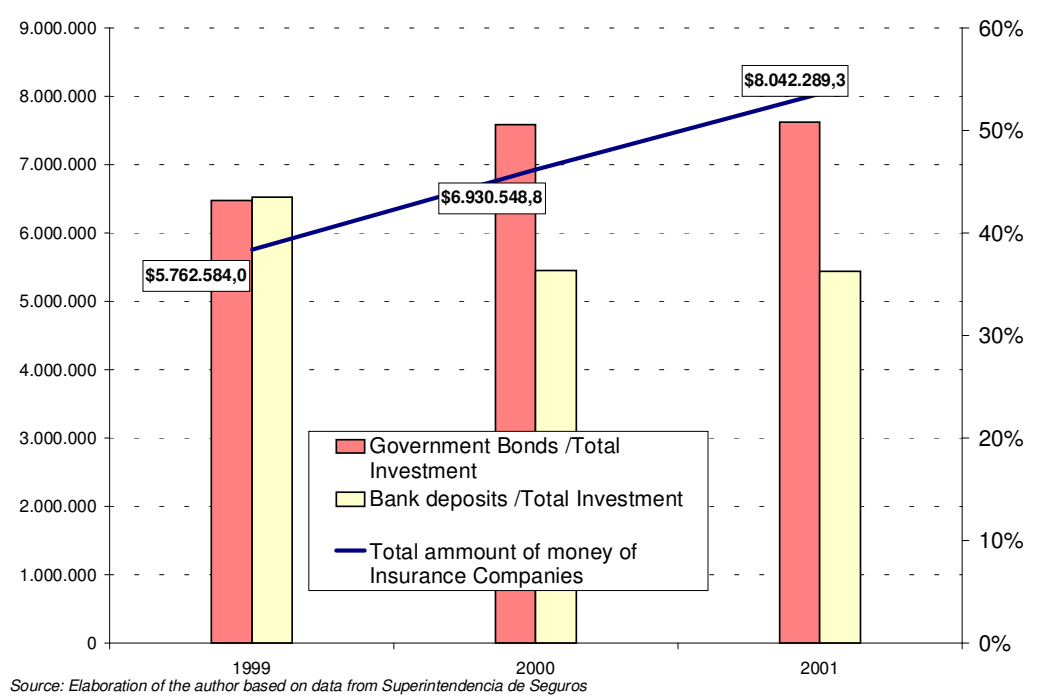

where we can see a deep bias towards bank deposits and government bonds (Mutual fund heavily invested as well in bank deposits $-68.2 \%$ and government bonds $-14.6 \%$ as well ${ }^{49}$ ). Data shows that most of the portfolio investment of institutional investors was headed to government bonds and bank deposits, but taking a look to the quality of assets of banks (that were acting as collateral for bank deposits):

Graph 16 Domestic assets (excluding cash holdings), credits and deposits of Argentinean banks (data April and October 1991-2001)

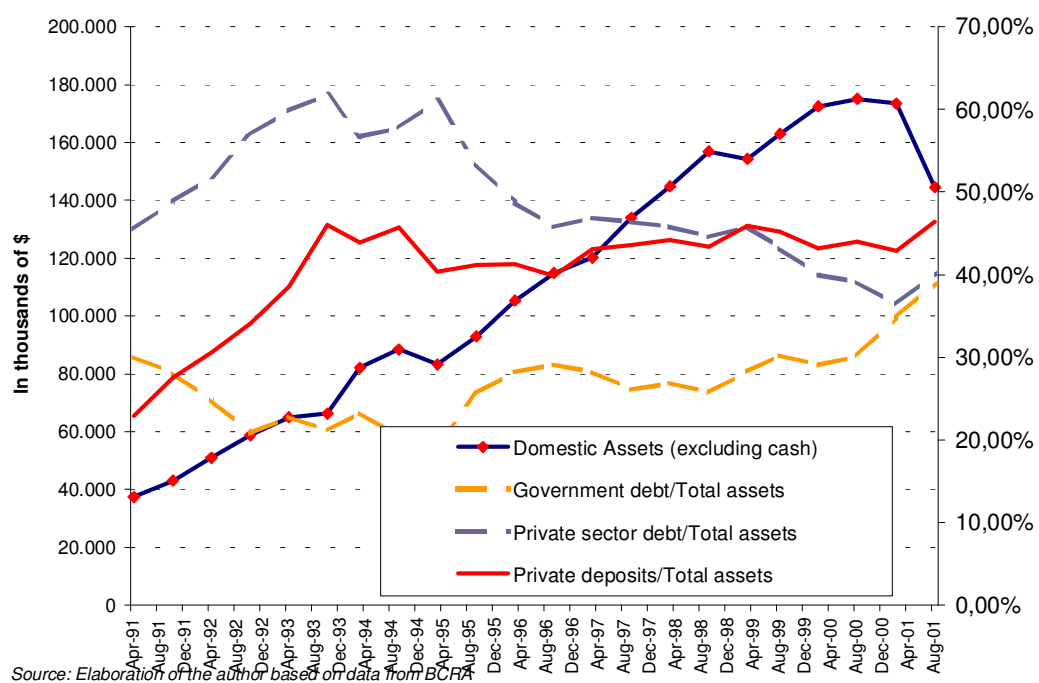

\footnotetext{
${ }^{48}$ Institutional investors include pension funds, mutual funds and insurance companies.

${ }^{49}$ Data from Argentina' s Central Bank (BCRA)
} 
so most of the final assets backing savings where either directly or indirectly government bonds. This is not a surprise since yields were attractive ${ }^{50}$ and bank regulations were biased toward investing in government bonds as well, because the capital required to invest in those assets was much lees than the one required to invest in companies, with the additional benefit of lowering transaction costs for banks (given there is only one borrower).

\subsubsection{The liquidity factor}

Another factor helping to explain the use of a particular financial instrument comes from analyzing the secondary capital market and its liquidity; the higher the liquidity for any instrument, the more attractive it will become. Argentinean bonds were highly liquid (approximately 25\% of trading of emerging markets bonds corresponded to argentinean bonds), something that can bee seen in the following graph for bond and equity trading:

\section{Graph 17 Average daily trading volume (Mercado de Valores de Argentina)}

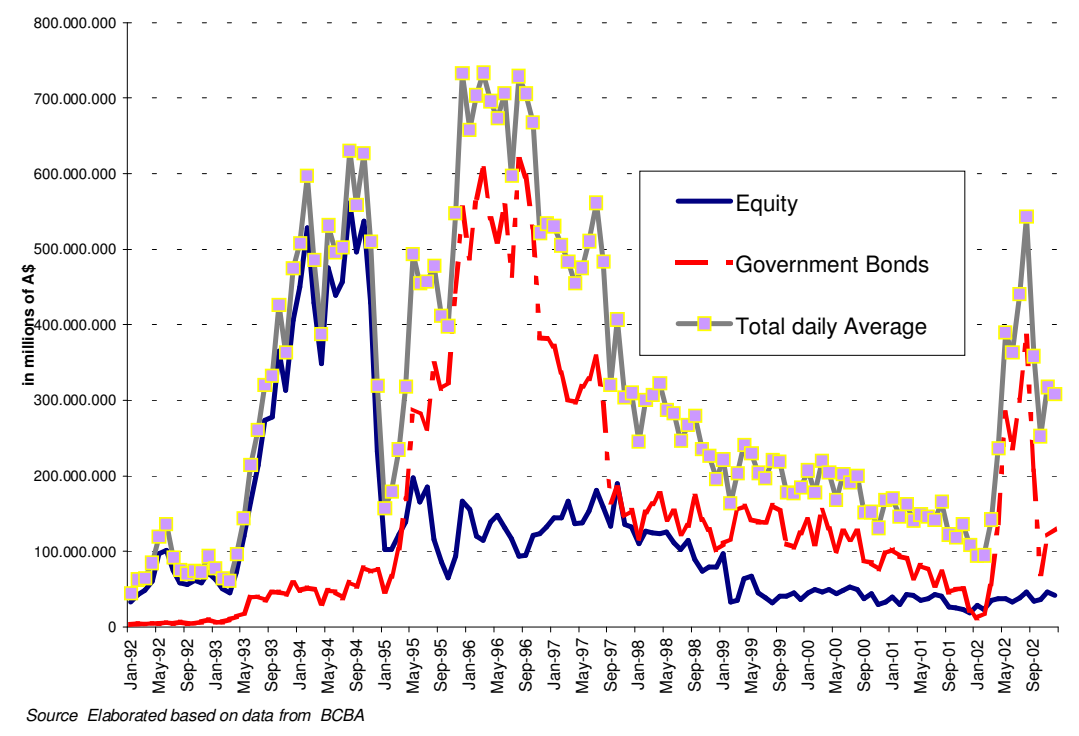

As it was noted in Dapena (2003), the trading volume follows the patter of international availability of funds (highly influenced for emerging markets by the FED interest rate), showing how capital flows affect the domestic capital market and its liquidity. The

${ }^{50}$ The yield on government bonds averaged $11 \%$ and bank deposit rate $7 \%$ (see Dapena 2004). 
interesting point comes from the instrument driving trading; before 1994 (Mexican crisis), the most traded instrument was equity while after the recovery, the most traded instrument became government bonds. This could have been partially motivated by Argentinean regulation creating the Pension Funds in 1994, where they became natural acquirers (as we saw in the previous point) of government bonds, supplying theses instruments with a high and attractive degree of liquidity. Individual investors could have followed the trend, increasing the attractiveness of bonds in spite of equities, and thus helping the equity market to languish.

\subsubsection{Other potential explanations}

As other potential explanations we can suggest:

- The high level of informal economy, that motivates unwillingness to disclose financial statements, hence making difficult the access to external credit;

- The potentially weak institutional framework;

and regarding capital markets:

- The lack of a distribution network of financial products ${ }^{51}$,

- The financial illiteracy of people (many people do not know that they can invest in capital markets),

- The lack of a connection that links all internal exchanges helping to reduce transaction costs.

This enumeration would likely be incomplete, but it is aimed to explore new avenues for further studies.

\section{Conclusions}

The present paper has approached the investment process and its financing from an aggregate or macro perspective, using in the process a contingent claims and real

\footnotetext{
${ }^{51}$ This potential explanation was suggested by Dagnino Pastore.
} 
options analysis. When analyzing the economic development of a variety of countries, we should not take into account only the rate of economic growth, but also the volatility of the rate, which drives considerations regarding the architecture of capital markets. Before the evidence of volatility in the rate of growth of the economy, we suggest that this volatility can translate into volatility of the market value of the stock of capital. If that was the case, the investment process, which takes into consideration the existence of uncertainty and irreversibility, is affected according to the theory of real options delaying the process of accumulation of capital and economic development. There are going to be times when the economy faces better growth perspectives and the value of capital is increased as a consequence, without translating that growth into effective investment processes, until it reaches a sufficiently attractive value.

It also gives rise to considerations regarding the financial architecture of the economy as a whole, where under conditions of uncertainty the best suited financial instrument would be equity liked ones, that helps absorb fluctuations by means of changes in price and market driven processes, without affecting credit rights. The internal level of saving becomes relevant as well in environments of high volatility, to provide resiliency to the economy. More volatile economies shall make use of more equity liked instruments with higher level of savings than their low volatility counterparts, which was not the case for Argentina, a historically highly volatile economy with also high degree of indebtedness (specially by the government) and low use of equities. For governments, the argentinean experience of linking debt payoff to the evolution of the economy, could be a good starting point. 


\section{References}

Allen F. y Gale D. (1988), "Optimal Security Design". The Review of Financial Studies 1 (3): 229-263.

Altman E. (1984), "A Further Empirical Investigation of the Bankruptcy Question", Journal of Finance (September): 1067-1089.

Bebczuk R. (1999), Essays in Corporate Saving, Financial Development and Growth. Tesis doctoral no publicada. University of Illinois at Urbana-Champaign.

Bebczuk R. (2000), Información Asimétrica en Mercados Financieros, Cambridge University Press, Cambridge U.K.

Bernanke B. y Gertle M. (1989), "Agency Costs, Net Worth and Business Fluctuations". American Economic Review Vol 79:1, 14-31.

Bernanke B. y Gertle M. (1990), "Financial Fragility and Economic Performance". The Quarterly Journal of Economics 87-114.

Black F., y Scholes M. (1973), ' ' The Pricing of Options and Corporate Liabilities' ' . Journal of Political Economy 81 (May-June): 637-659.

Brealey R. y Myers S. (1996). Principles of Corporate Finance. Mc Graw Hill.

Caballero R. (2000a), "Aggregate Volatilty in Modern LatinAmerica: Causes and Cures", NBER working paper.

Caballero R. (2000b), "Macroeconomic Volatility in Latinamerica: A View and Three Cases Studies ", NBER working paper.

Caballero R. y Krishnamurty A. (1998), "Emerging Market Crises: an Asset Market Perspective", NBER Working paper. 
Caballero R. y Krishnamurty A. (2001), "International and Domestic Collateral Constraints in a Model of Emerging Market Crises", Journal of Monetary Economics 48 (3) 513-548.

Calvo G. (1996), "Varietes of Capital Market Crises", en The Debt Burden and its Consequences for Monetary Policy, International Economic Association, Macmillan.

Calvo G. (1998), "Capital Flows and Capital Market Crises", Journal of Applied Economics 1 (1) 35-54.

Calvo G. (1999), "Contagion in Emerging markets: when Wall Street is a carrier", mimeo, University of Maryland.

Cox J., Ross, S., y Rubinstein M. (1979), ' ' Option pricing: A simplified approach' ' . Journal of Financial Economics 7, no. 3:229-263

Dapena, J. (2003), "Absorción de shocks en economías volátiles: ahorro a través de acciones en el mercado de capitales - el caso argentino 1993 -2001" Working paper 257 Universidad del CEMA.

Dapena, J. y Dapena J.L. (2003), "Sistemas de información en Pymes y acceso al crédito en contextos de asimetrías de información". Working paper Universidad del CEMA.

DeAngelo H. y Masulis R. (1980), "Optimal Capital Structure under Corporate and Personal Taxation". Journal of Financial Economics, March 1980, 3-30

Dixit A. y Pindyck R. S. (1994), Investment under Uncertainty, Princeton University Press, Princeton, N.J.

Fisher I. (1930), The Theory of Interest. Reprinted in 1956 by Augustus M. Kelley Publishers New York. 
Gale D. y Hellwig M. (1985), "Incentive Compatible Contracts: the one period problem". Review of Economic Studies 11: 647-663.

Garber P. (1990), "Famous First Bubbles". Journal of Economic Perspectives vol 4 2: $35-54$.

Gray D., Merton R. C. y Bodie Z., (2003), ' ' A New Framework for Analyzing and Managing Macrofinancial Risks of an Economy' ' . MF Risk Working Paper-103.

Greenwald B. y Stiglitz J. (1993), "Financial Markets Imperfections and Business Cycles". The Quarterly Journal of Economics Feb 77-114.

Hirschleifer J. (1958), "On the Theory of Optimal Investment Decision", Journal of Political Economy 66: 329-352.

Ingersoll J. (1987), Theory of Financial Decision Making, Studies in Financial Economics. Rowman \& Littlefield Publishers inc.

Jensen M. y Meckling N. (1976), "Theory of the Firm: Managerial Behaviour, Agency Costs and Ownership Structure". Journal of Financial Economics 3 (4): 305-360.

Kiyotaki N. y Moore J. (1997), "Credit Cycles". Journal of Political Economy Vol 105 no 2: 211-248.

Laporta R., Lopez de Silanes F., Shleifer A. Y Vishny R. (1997), "Legal Determinants of External Finance", Journal of Finance 52 (3): 1131-1150.

Levine R. (1997), "Financial Development and Economic Growth: Views and Agenda", Journal of Economic Literature 35 (2): 688-726.

Levine R. y Zerbos S. (1998), "Stock Markets and Economic Growth", American Economic Growth 88 (3): 537-558.

Levine R., Loayza N. y Beck T. (2000), "Financial Intermediation and Growth: Casuality and Causes", Journal of Monetary Economics 46 (August): 31-77. 
Lewis K. (1999), "Trying to Explain Home Bias in Equities and Consumption", Journal of Economic Literature 37 (2): 571-608.

Leland H. y Pyle D. (1977), "Informational Asymmetries, Financial Structure and Financial Intermediation". Journal of Finance May 371-388.

Mc Donald R. y Siegel D. (1984), ' ' Option Pricing When the Underlying Asset Earns a Below-Equilibrium Rate of Return: A Note' 'Journal of Finance (March), 261-265

Mc Donald R. y Siegel D. (1985), ' ' Investment and the Mation of Firms When there is an Option to Shut Dow' 'International Economic Review 26 (June), 331-349

Mc Donald R. y Siegel D. (1986), ' ' The Value of Waiting to Investuarterly Journal of Economics (November) 101, 707-728

Merton R. C. (1973), ' ' đdry of Rational Option Pricing' 'Bell Journal of Economics and Management Science 4, no. 1: 141-183.

Merton R. C. (1974), ' ' On the Pricing of Coporate Debt: the Risk Structure of Interest Rates' 'Jaurnal of Finance 29: 449-470.

Merton R. C. (1977), " On the Pricing of Contingent Claims and the ModiglianMiller Theorem' 'Journal of Financial Economics 5: 241-250.

Merton R. C. (1992), Continuous Time Finance. Blackwell Publishers

Miller M. (1977), "Debt and Taxes". Journal of Finance May 1977, 261-297.

Miller M. (1998), "Financial Markets and Economic Growth", Journal of Applied Corporate Finance 11 (3): 8-15.

Modigliani F. y Miller M. (1958), "The Cost of Capital, Corporation Finance and the Theory of Investment", American Economic Review 48: 261-297.

Myers S. (1977), ' ' Determinants of Corporate Borrowing'Jóurnal of Financial Economics 5 147-176.

Myers S. (1984), ' ' The Capital Structure PuzzleJ'aurnal of Finance 575-592. 
Myers S. y Majluf N. (1984), ' ' Corporate Financing and Investmtemecisions when Firms have Information that Investors do not have ". Journal of Financial Economics June 187-221.

Neftci S. (1996), An Introduction to the Mathematics of Financial Derivatives. Academic Press.

Obstfeld M. y Rogoff K. (1996), Foundations of International Macroeconomics, The MIT Press

Rajan R. y Zingales L. (1998), "Financial Dependenc Growth", American Economic Review 88 (3):559-586.

Ridditz C. (2003), "Liquidity Needs and Vulnerability to Financial Underdevelopment", mimeo MIT.

Sachs J. y Larraín F. (1994) Macroeconomía en la Economía Global. Prentice Hall Latinoamericana.

Stiglitz J. (1969), "A Re-examination of the Modigliani Miller Theorem". American Economic Review Dec, 784-793.

Stiglitz J. y Weiss A. (1981), "Credit Rationing in Markets with Imperfect Information", American Economic Review 71 (3): 393-410.

Tobin J. (1969), "A General Equilibrium Approach to Monetary Theory". Journal of Money, Credit and Banking 1 (Febrero): 15-29.

Trigeorgis L. (1988), ' ' A Conceptual OptionFramework for Capital Budgeting' ' . Advances in Futures and Options Research 3:145-167.

Trigeorgis L. (1997), Real Options: Managerial Flexibility and Strategy in Resource Allocation. The MIT Press, Cambridge Massachussets. 
Weitz C. y Bebczuk R.. (2001), "La Argentina obligada a buscar un camino financiero propio" Article published the 15 of December, 2001 by Grupo Estratégico de Servicios Financieros (GESF) of the Ministerio de Economía de la Nación.

\section{Data web sites}

Bloomberg (www.bloomberg.com)

World Bank Database

Banco Central de la República Argentina (www.bcra.gov.ar)

IMF Database

Bolsa de Comercio de Buenos Aires (www.bolsar.com.ar)

Centro de Economía Aplicada de Universidad del CEMA (www.cema.edu.ar/cea/index.html)

Federación Internacional de Bolsas de Valores (www.fibv.com)

Instituto Argentino de Mercado de Capitales (www.merval.sba.com.ar)

Instituto Nacional de Estadísticas y Censos (www.indec.gov.ar)

Superintendencia de Seguros de la Nación (www.ssn.gov.ar)

Superintendencia de Administradoras de Fondos de Jubilación y Pensión (www.safjp.gov.ar)

\section{Articles}

Apertura (2003),. "De la Tiza a la Computadora". Edition 122 of June, 2003.

The Economist (2001), A Survey of Global Equity Markets. Edition of the 5 of May, 2001.

The Economist (1999), School Brief - Finance: trick or treat? Edition of the 23 of October, 1999. 
Appendix A - Countries and stock index taken for the regression analysis

\begin{tabular}{ll}
\hline Country & Index \\
\hline Argentina & MERVAL Index \\
Australia & AS30 Index \\
Austria & ATX Index \\
Belgium & BEL20 Index \\
Brazil & IBOV Index \\
Canada & SPTSX Index \\
Chile & IPSA Index \\
China & SHCOMP Index \\
Czech Republic & PX50 Index \\
Denmark & KFX Index \\
Egypt & EFGIEFG Index \\
France & CAC Index \\
Germany & DAX Index \\
Greece & ASE Index \\
Hong Kong & HSI Index \\
India & SENSEX Index \\
Indonesia & JCI Index \\
Israel & TA-100 Index \\
Italy & MIBTEL Index \\
Japan & NKY Index \\
Korea & KOSPI Index
\end{tabular}

\begin{tabular}{ll}
\hline Country & Index \\
\hline Malaysia & KLCI Index \\
Mexico & MEXBOL Index \\
Netherlands & AEX Index \\
New Zealand & NZSE40 Index \\
Norway & OBX Index \\
Pakistan & KSE Index \\
Peru & IGBVL Index \\
Phillipines & PCOMP Index \\
Portugal & BVLX Index \\
Russia & RTSI\$ Index \\
Singapur & STI Index \\
Slovakia & SKSM Index \\
Spain & MADX Index \\
Sri Lanka & CSEALL Index \\
Sweden & SBX Index \\
Switzerland & SMI Index \\
Thailand & SET Index \\
Turkey & XU100 Index \\
United Kingdom & UKX Index \\
United States & SPX Index \\
&
\end{tabular}


Appendix B - Formal interactions arising from valuation methods between value and rate of growth

According to the standard methodology of calculation of discounted cash flows, the current present value of a perpetual stream of future flows is:

$\mathrm{V}_{\mathrm{t}}=\frac{\mathrm{FF}_{\mathrm{t}+1}}{(1+\mathrm{k})} * \frac{\mathrm{FF}_{\mathrm{t}+2}}{(1+\mathrm{k})^{2}}+\frac{\mathrm{FF}_{\mathrm{t}+3}}{(1+\mathrm{k})^{3}}+\ldots . . .=\sum_{\mathrm{i}=1}^{\infty} \frac{\mathrm{FF}_{\mathrm{t}+\mathrm{i}}}{(1+\mathrm{k})^{\mathrm{i}}}$

where $\mathrm{Vt}$ represents the present value at time $\mathrm{t}$ of future flows of funds $\mathrm{FF}_{\mathrm{t}+\mathrm{i}}$, and $\mathrm{k}$ is the relevant discount rate. If the flow of funds is constant in the form $\mathrm{FF}_{\mathrm{t}+1}=\mathrm{FF}_{\mathrm{t}+2}=\ldots \ldots \mathrm{FF}_{\mathrm{t}+\mathrm{i}}$, we obtain:

$\mathrm{V}_{\mathrm{t}}=\mathrm{FF}_{\mathrm{t}+1} * \sum_{\mathrm{i}=1}^{\infty} \frac{1}{(1+\mathrm{k})^{\mathrm{i}}}=\mathrm{FF}_{\mathrm{t}+1} * \sum_{\mathrm{i}=1}^{\infty} \lambda^{\mathrm{i}}$

where

$\lambda=1 /(1+\mathrm{k})$

by substracting $\lambda \mathrm{Vt}$ from (D.2) we obtain:

$\mathrm{V}_{\mathrm{t}}-\lambda \mathrm{V}_{\mathrm{t}}=\mathrm{FF}_{\mathrm{t}+1} \lambda$

where Vt would become:

$\mathrm{V}_{\mathrm{t}}=\frac{\mathrm{FF}_{\mathrm{t}+1} \lambda}{1-\lambda}=\frac{\mathrm{FF}_{\mathrm{t}+1}}{\mathrm{k}}$

Following the same derivations, if the flow of funds grows at a steady rate g, we obtain:

$\mathrm{Vt}=\mathrm{FFt}+1 /(\mathrm{k}-\mathrm{g})$

where $\mathrm{k}$ stands for the relevant discount rate and $\mathrm{g}$ is the rate of growth. This formula stems from: 
$\mathrm{V}_{\mathrm{t}}=\frac{\mathrm{FF}_{\mathrm{t}} *(1+\mathrm{g})}{(1+\mathrm{k})} * \frac{\mathrm{FF}_{\mathrm{t}+2} *(1+\mathrm{g})^{2}}{(1+\mathrm{k})^{2}}+\frac{\mathrm{FF}_{\mathrm{t}+3} *(1+\mathrm{g})^{3}}{(1+\mathrm{k})^{3}}+\ldots \ldots=\sum_{\mathrm{i}=1}^{\infty} \frac{\mathrm{FF}_{\mathrm{t}+\mathrm{i}} *(1+\mathrm{g})^{\mathrm{i}}}{(1+\mathrm{k})^{\mathrm{i}}}$

but being $\mathrm{FF}_{\mathrm{t}+1}=\mathrm{FF}_{\mathrm{t}}(1+\mathrm{g}), \mathrm{FF}_{\mathrm{t}+2}=\mathrm{FF}_{\mathrm{t}}(1+\mathrm{g})^{2}, \ldots . . \mathrm{FF}_{\mathrm{t}+\mathrm{i}}=\mathrm{FF}_{\mathrm{t}}(1+\mathrm{g})^{\mathrm{i}}$, we have

$$
\mathrm{V}_{\mathrm{t}}=\mathrm{FF}_{\mathrm{t}} * \sum_{\mathrm{i}=1}^{\infty} \frac{(1+\mathrm{g})^{\mathrm{i}}}{(1+\mathrm{k})^{\mathrm{i}}}=\mathrm{FF}_{\mathrm{t}+1} * \sum_{\mathrm{i}=1}^{\infty} \lambda^{\mathrm{i}}
$$

where now $\lambda=(1+\mathrm{g}) /(1+\mathrm{k})$, and to ensure convergence $\mathrm{g}<\mathrm{k}$. If we substract $\lambda \mathrm{Vt}$ from $\mathrm{Vt}$, we obtain:

$\mathrm{V}_{\mathrm{t}}-\lambda \mathrm{V}_{\mathrm{t}}=\mathrm{FF}_{\mathrm{t}} \lambda$

where Vt would become the one showed in (D.6)

$\mathrm{V}_{\mathrm{t}}=\frac{\mathrm{FF}_{\mathrm{t}+1} \lambda}{1-\lambda}=\frac{\mathrm{FF}_{\mathrm{t}+1}}{\mathrm{k}-\mathrm{g}}$

The model can be easily extend for different rates of growth or finite periods of time, being the interesting point the relation between the Value $\mathrm{V}$ and the rate of growth $\mathrm{g}$ in the form:

$\mathrm{Vt}=\mathrm{f}(\mathrm{g})$ 
Appendix C - Relationship between rate of return of the argentinean stock index and rate of change of aggregate investment

The following graph shows annual data regarding the rate of return of the argentinean stock index (Merval) and the percentage variation of aggregate investment (IBIF) for the period 19932001:

Graph C1 Annual changes in percentage of Merval Index and aggregate investment

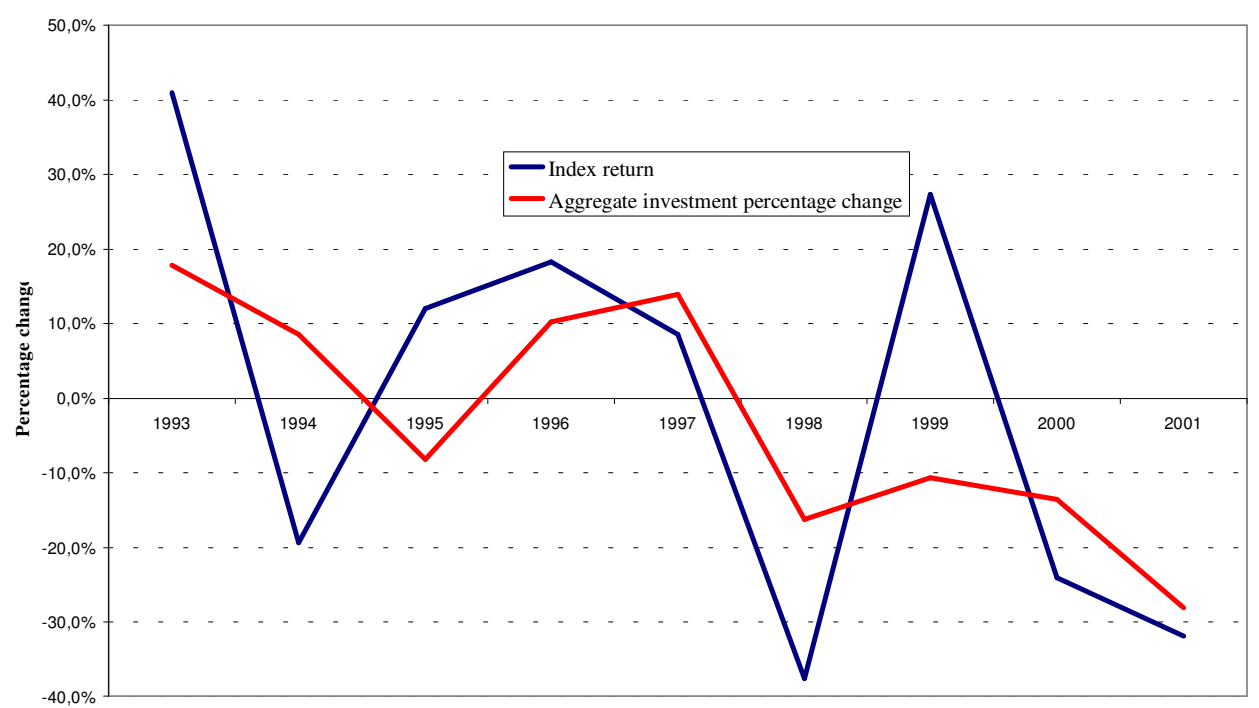

